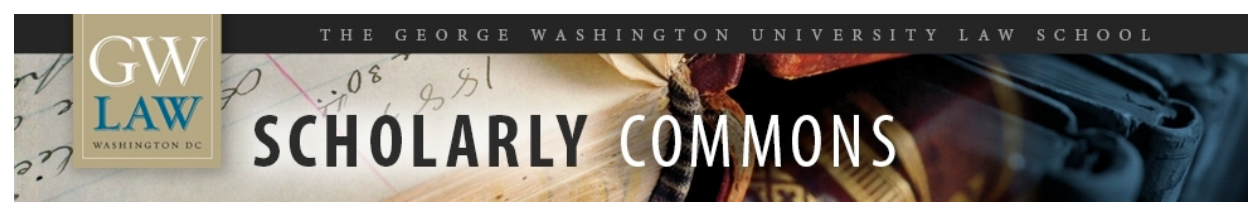

\title{
The United States and the International Court of Justice: Coping with Antinomies
}

\section{Sean D. Murphy}

George Washington University Law School, smurphy@law.gwu.edu

Follow this and additional works at: https://scholarship.law.gwu.edu/faculty_publications

Part of the Law Commons

\section{Recommended Citation}

Sean D. Murphy, The United States and the International Court of Justice: Coping with Antinomies in THE UNITED STATES AND INTERNATIONAL COURTS AND TRIBUNALS (Cesare Romano, ed., 2008).

This Article is brought to you for free and open access by the Faculty Scholarship at Scholarly Commons. It has been accepted for inclusion in GW Law Faculty Publications \& Other Works by an authorized administrator of Scholarly Commons. For more information, please contact spagel@law.gwu.edu. 


\section{The United States and the International Court of Justice: Coping with Antinomies}

Sean D. Murphy*

\section{Introduction}

Since 1946, the United States has had an uneasy relationship with the International Court of Justice (ICJ or World Court or Court). On the one hand, the United States embraces the rule of law within its own society and, in principle, within the international system of states. The United States has been and remains an active participant in cases before the Court, appearing before it several times, more than any other state, even in recent years. On the other hand, the United States has never been willing to submit itself to the plenary authority of the Court, and has typically reacted negatively to decisions by the Court that are adverse to U.S. interests. As is well known, in reaction to decisions that were reached by the Court, the United States refused to participate in the proceedings on the merits of the case brought by Nicaragua in 1984, withdrew from the Court's compulsory jurisdiction in 1986, and recently terminated its acceptance of the Court's jurisdiction over disputes arising under the Vienna Convention on Consular Relations.

This chapter addresses certain salient aspects of the United States relationship with the International Court of Justice. Following this Introduction, Part II briefly sets forth three antinomies (i.e. equally rational but conflicting principles) in U.S. foreign relations that have had important ramifications for the U.S. relationship with the Court from the outset. First, the United States operates on the basis of conflicting principles with respect to the relevance of international law and institutions for U.S. foreign policy. These conflicting principles have been referred to

* Professor of Law, George Washington University. My thanks for the opportunity to present this chapter at the T.M.C. Asser Institute in the Hague (May 2005), at George Washington University Law School (May 2006), and at Georgetown Law School (February 2007), and to Brooke Marcus (J.D. 2006) and José Arvelo-Vélez (J.D. 2006) for outstanding research assistance. As a matter of full disclosure, the author served as counsel for the United States in several of the cases discussed in this essay. 
broadly in international relations theory as "realism" and "institutionalism." Although discussion of the intricacies of such theories is beyond the scope of this chapter, realism at its core emphasizes the use of coercive state power in resolving inter-state disputes. The realist has little faith in international institutions generally, insisting that they (including institutions for international dispute resolution) do not exert any independent influence on state behavior. The institutionalist asserts that the logic of realism does not adequately explain cooperation among states, and thus places greater weight on the role that independent, judicial decision-making has upon inter-state relations. The institutionalist sees long-term value in international courts as a means of efficiently and effectively coordinating state behavior. Both approaches represent powerful and deep-seated instincts in the American attitude toward international law and institutions although, of the two, realism historically has tended to dominate.

Second, the United States operates on the basis of conflicting principles with respect to whether states should be treated as equal sovereigns or as units characterized by inescapable power differentials. While the United States historically has articulated a desire for cooperation with other states as co-equal sovereigns - and, indeed, has been in the vanguard in many respects in the promotion and development of international law and institutions built around the concept of sovereign equality - the United States has innate historical and cultural characteristics that push it toward an attitude of "exceptionalism" in its foreign policy, claiming itself entitled, formally and informally, to be treated differently from other states. Although similar in nature to the first antinomy stated above, this antinomy reflects certain factors quite unique to the United States, including its present role as the pre-eminent superpower, as an economic powerhouse, and as a country in certain respects uniquely insulated from vicissitudes of international relations. With respect to the U.S. relationship with the International Court, this antinomy pulls the United States toward the Court as an institution before which all states are equal under law, but pushes it away when the Court fails to accommodate the special role of the United States on matters such as the maintenance of international peace and security.

Third, the United States operates on the basis of conflicting principles with respect to whether international law should be "embedded" in U.S. law, including the manner in which international courts relate to U.S. law. On the one hand, the United States at its founding saw 
adherence to international obligations as an important means of establishing the international legitimacy and security of a nascent republic, and so adopted constitutional and judicial principles that promoted the idea of international law as being a part of national law and as superior to the law of the several states. On the other hand, the United States has developed democratic and constitutional traditions that make it difficult to adhere to and to implement internally international law. With respect to its democratic tradition, the United States has always accepted the importance and significance of a judiciary for the resolution of disputes, but has also viewed unelected judges as potential agents for usurping popular governance, a concern that is aggravated when the judges in question are non-American and issuing their decisions from afar. Further, U.S. constitutional law creates significant obstacles to adherence to international law and institutions by dividing power between the President and the legislature, and by maintaining a federal system that accords extensive rights to the several states.

Part III suggests that the International Court was initially designed to accommodate such antinomies (which also exist with respect to other states, to varying degrees) by providing the means for mediating between these conflicting principles. For example, the formal manner for selecting judges and the types of jurisdiction granted to the Court are a means for satisfying and cultivating those U.S. principles that favor the existence and participation in a global court, while at the same time acknowledging certain limitations on the Court in an effort not to aggravate conflicting principles. These techniques for mediating antinomies are discussed in the context of the history of the U.S. relationship with the Court from its inception to modern times.

Part IV then briefly highlights the unfolding of these antimonies in some of the recent cases of the United States before the Court, with particular attention to the Oil Platforms case, the Israeli Wall advisory opinion, and the Breard/LaGrand/Avena cases. While the United States fully participated in these cases and did not denounce the Court's decisions as without basis in law, the cases have brought the Court into square conflict with U.S. visions of realism, exceptionalism, and constitutional autonomy.

Among other things, Part $\mathrm{V}$ suggests that certain formal and informal means for mediating these antimonies may have been forgotten in the past twenty years, leading to a point where the Court readily finds fault in the United States and the United States holds the Court in 
very low regard. In particular, while the Court's concern with its reputation and legitimacy in the first thirty years of its existence served as an important informal constraint in the Court's relationship with the United States, over the past twenty years that same concern has led to repeated clashes. The chapter concludes that these antinomies are unlikely to be resolved through the further development of formal or informal mediating techniques. In the near term, American policymakers will seek to avoid any involvement in matters before the Court, while the Court will embrace opportunities to speak to the legality of U.S. actions.

\section{Antinomies in the U.S. Relationship with the ICJ}

An "antinomy" is a contradiction in principles that seem equally necessary and reasonable. In U.S. foreign relations, three core antinomies simultaneously pull the country toward and push it away from the idea of a meaningful international court. First, there is the conflict between "realism" and "institutionalism" in the way America thinks about securing its interests. Second, there is the conflict between the U.S. vision of itself as a unique entity that should not be subject to the same constraints of international law and institutions to which other states should be exposed, and the U.S. vision of engaging with co-equal sovereigns through uniform rules on trade, human rights, and other important issues. Third, there is the conflict between, in the first instance, U.S. democratic traditions that promote the autonomy of the U.S. legal system and local governance over local issues and, in the second instance, the U.S. willingness to embed its national law in international law. These antinomies - which are

presented as broad concepts though they in practice have overlapping features - have had and will continue to have significant repercussions for the relationship with the International Court.

\section{1.a. American Realism Versus Institutionalism}

One antinomy of significance arises from the well-known divide within American 
society, broadly stated, between realism and institutionalism lines of thinking. ${ }^{1}$ The social contract theory advanced by Thomas Hobbes, ${ }^{2}$ John Locke, ${ }^{3}$ and Jean-Jacques Rousseau ${ }^{4}$ to justify the origin of the state focused on the state as a creation by free individuals whose interests - security, freedom, order, justice, and welfare - the state must recognize and serve. As far as relations among states, Hobbes saw an environment of anarchy in which states fear each other, such that a state must use its military and economic power to pursue strategies and policies that advance that state's interests, which invariably conflict with the interests of other states. While bargains may be struck between states that serve their mutual interests, such bargains are not and should not be driven by abstract ethical, moral, or legalistic considerations, and once struck are often temporary or imposed coercively by one of the parties. Thus, international "law" (or rules or norms) and international "institutions" (or "regimes") may exist, but they do not exert independent influence on states. To the extent that states are seen as abiding by such law, it is simply because political or economic factors encourage them to do so, not because of a fidelity to a "legal" system. Rather, states strive relentlessly to increase their relative power position visà-vis rival states regardless of international law or institutions. Frequently referred to as "realism" in international relations theory, this line of thinking appears to be deeply entrenched in U.S. policy-making; legions of American policy-makers are fully versed in the seminal "realist" writings of Hans Morganthau, Thomas Schelling, and Kenneth Waltz. ${ }^{5}$

The flip side of realism is "institutionalism," which also has a place in U.S. policymaking. Institutionalists assert that the contemporary nature of inter-state relations is

${ }^{1}$ There is, of course, an extraordinarily rich array of theories on international law and politics that cannot be done justice within this chapter. A sampling of these theories appears in Foundations of International Law and Politics (Oona A. Hathaway \& Harold Hongju Koh eds., 2005). For present purposes, very simplified models are used.

2 Thomas Hobbes, Leviathan (Macmillan 1962) [1641].

${ }^{3}$ John Locke, Second Treatise of Government [1698] (Thomas P. Peardon ed., Prentice Hall, 1952) [1698].

${ }^{4}$ Jean-Jacques Rousseau, On the Social Contract: Discourse on the Origin of Inequality; Discourse on Political Economy (Donald A. Cress trans. \& ed., Hackett, 1987) [1762].

${ }^{5}$ Hans J. Morgenthau, Politics Among Nations: The Struggle for Power and Peace (2d ed. 1955); Thomas C. Schelling, The Strategy of Conflict (1960); Kenneth Waltz, Theory of International Politics (1979). 
demonstrably not Hobbesian; rather, there is an extraordinary amount of cooperation among states that realism theory fails to explain. States pursue their national interests, but those interests include a desire for international law and institutions, such as impartial inter-state dispute settlement, since cooperation often yields far greater benefits than non-cooperation. ${ }^{6}$ Among other things, institutionalists seek to develop a web of norms that will compel just, moral and equitable behavior among states; to end warfare through use of collective security, disarmament, and even criminal punishment; to use human rights as a normative tool for restraining government abuses of its people; and to make the world safe for democracy. The intellectual origins of institutionalism lie in the writings of Immanuel Kant, who called upon states to establish a league of peace to prevent war. ${ }^{7}$ At key points in American history, this line of thinking dominated U.S. foreign policy; typically reference is made to Woodrow Wilson's Fourteen Points after World War I, to U.S. support for the myriad multilateral institutions that arose after World War II, and to the emphasis on human rights in the foreign policies of certain presidents, such as Jimmy Carter. At any given time, U.S. foreign policy may have elements of both realism and institutionalism. The current Bush administration is realist in its tendency to resist empowerment of international organizations, but has elements of institutionalism in its neo-conservative emphasis on the promotion of democracy.

This broad conflict in the U.S. attitude to foreign relations has affected the relationship with the Court. On the one hand, institutionalism in the United States favors the existence of an effective and useful global court, whether or not the U.S. wins all its cases before the Court. For some, the very idea of a global court with an impartial panel of judges is strongly compelling;

\footnotetext{
${ }^{6}$ See, e.g., Robert O. Keohane, After Hegemony: Cooperation and Discord in the World Political Economy
} (1984). Institutionalists are not interested in international courts simply out of a desire for international institutions. Though historically there have been "idealists" who favor international courts due to a belief that world government helps lead to world peace (and thus are necessarily a good thing), institutionalists favor institutions if they serve a useful purpose. Hence, while institutionalists as a general matter are more favorably inclined towards seeing the potential for international courts, much turns on whether any given court is operating in an effective and efficient way.

${ }^{7}$ Immanuel Kant, Perpetual Peace: A Philosophical Essay (M. Campbell Smith, trans., A. Robert Caponigri ed., Liberal Arts Press, 1948) [1795]. 
Thomas Franck has referred to such a vision as "messianic" - a belief that the rule of law institutions that have worked so well internally for the United States must be replicated on the international level. ${ }^{8}$ On the other hand, realism in the United States wants to maintain the ability of the country to protect its national interests through resort to unilateral power, and to that end has opposed a global court with plenary jurisdiction over international disputes involving it. For Franck, this is a "chauvinist" vision, one that views the rule of law known within the United States as unique to American history, culture, and values, such that replication of the rule of law internationally is not only implausible but threatens national values and institutions. ${ }^{9}$ While the institutionalist strand led to the acceptance of the Court's compulsory jurisdiction in 1946 (discussed further in Part III), the realist strand virtually eviscerated that acceptance by attaching reservations to the acceptance. The presence, and even swinging back and forth, of these lines of thinking has fostered a constant tension between Washington D.C. and The Hague, especially in recent years. Arguably the United States has pursued an impossible position of both embracing the idea of the Court and yet distancing itself from the inevitable effects of that idea.

This antinomy is not unique to the United States; other states have similar lines of thinking in their foreign policy. Indeed, the structural aspects built into the ICJ that are discussed in Part III - aspects that seek to mediate between the desire of states for an impartial, permanent judicial forum, and the desire of states to control their exposure to ICJ decision-making - may be seen as an effort to mediate between institutionalism and realism among all states. A further tension that arises, however, lies in the differences among states in how they strike a balance between these lines of thinking in their relationship to the Court. On one end of the spectrum where realism dominates - lie China and Russia, where the institutionalism line of thinking has never taken hold. Those states see no national interest in being exposed to the jurisdiction of the

${ }^{8}$ Thomas Franck, Messianism and Chauvinism in America's Commitment to Peace Through Law, in The International Court of Justice at a Crossroads 3, 6 (Lori F. Damrosch ed., 1987); see also Mark Weston Janis, The American Tradition of International Law: Great Expectations, 1789-1914 (2004) (finding that "to a surprising extent, the international courts of today were the work of nineteenth-century American Utopians by and large untrained in the law.").

${ }^{9}$ Franck, supra note 8 , at 6. 
Court and have succeeded in never appearing before the Court in a contentious case. In effect, China and Russia have no relationship with the Court, other than the presence of a judge of their nationality on the Court. A little further along the spectrum is the United States, whose relationship with the Court is dominated by realism but with a patina of institutionalism.

Much further along the spectrum - moving into where institutionalism dominates - are the Europeans. For Europeans, the carnage of two world wars left them no choice but to opt for an institutionalist approach to foreign relations; a forsaking of national sovereignty and national prerogatives in favor of supra-national institutions (the European Union, with its European Court of Justice, and the Council of Europe, with its the European Court of Human Rights) that would generate and interpret law that would bind European states. As such, their attitude toward the International Court leans towards the institutionalist end of the spectrum. Of the twenty-five members of the European Union, for example, fourteen have accepted the Court's compulsory jurisdiction. ${ }^{10}$ Finally, also largely on the institutionalism side of the spectrum are many of the developing states, such as Argentina, Democratic Republic of the Congo, Djibouti, or Nicaragua, all of whom currently have cases pending at the Court. For them, the balance is also oriented toward the institutionalism approach because in most instances those states cannot rely on military or economic power to advance their national interests. By contrast, to the extent that embracing the Court provides a means for resolving intractable disputes among developing states, and a possible means for restricting the power of Western developed states, the World Court provides developing states with leverage that they would not otherwise have on their own. So while many developing nations have declined to expose themselves to the uncertainty of the Court's compulsory jurisdiction, they strongly favor the Court's existence, are quite interested in using it when possible to resolve disputes with neighbors, and are willing to use it on occasion against more powerful states, such as Djibouti's current case against France.

Differences in attitudes among these groups create tension. Realism-oriented states wish to downplay the authority and significance of the Court, wish to see it adopt a narrow approach

10 Austria, Belgium, Denmark, Finland, Greece, Hungary, Luxembourg, Netherlands, Poland, Portugal, Slovakia, Spain, Sweden, and United Kingdom have adhered to the Court's compulsory jurisdiction. Cyprus, Czech Republic, Estonia, France, Germany, Ireland, Italy, Latvia, Lithuania, Malta, and Slovenia have not. 
to its jurisdiction, and are quick to challenge its integrity and impartiality whenever the opportunity arises. Conversely, institutionalism-oriented states tend to do the opposite, thus leading to serious divergences among states regarding the proper functioning, aim and use of the Court.

\section{1.b. American Exceptionalism Versus Sovereign Equality}

A second antinomy of significance arises from the conflict between accepting an international system fundamentally predicated on the equality of all states, and, at the same time, insisting (formally and informally) upon special prerogatives for major powers, most particularly the United States itself. ${ }^{11}$ While there are links with the "realism" line of thinking discussed above, exceptionalism is a somewhat different concept, in that whether a realism or institutionalism outlook is taken, the United States is often captivated by a belief that it simply should not be treated just like every other state.

The belief in the sovereign equality of all states is a fundamental principle of U.S. engagement in the international system. The international legal system, which the United States has done much to promote, is constructed around the concept of "the state", and the concept of all states having the same fundamental rights and obligations as an incident of their statehood. As asserted in the General Assembly's famous Declaration on Principles of International Law:

All States enjoy sovereign equality. They have equal rights and duties and are equal members of the international community, notwithstanding differences of an economic, social, political or other nature. In particular, sovereign equality includes the following elements:

\section{States are juridically equal;}

${ }^{11}$ For a detailed discussion of how international law generally mediates between the principle of sovereign equality and a principle favoring prerogatives of great powers, see Gerry Simpson, Great Powers and Outlaw States (2004). 
2. Each State enjoys the rights inherent in full sovereignty;

3. Each State has a duty to respect the personality of other States;

4. The territorial integrity and political independence of the State are inviolable;

5. Each State has the right freely to choose and develop its political, social, economic and cultural systems. ${ }^{12}$

For this reason, the United States accepts that in the plenary bodies of international organizations, and at international negotiations of new treaties, tiny states in terms of territory or population (such as Nauru) are entitled to the same formal status as behemoths (such as China).

At the same time, the conflicting vision of American exceptionalism pushes back against such notions of equality. Thus, in constructing a U.N. Security Council, the United States should be a permanent member with special rights and privileges that protect it from Security Council action. When establishing a World Bank or International Monetary Fund, a weighted voting system should be created that protects U.S. influence in the development of international economic policy. More recently, when creating international criminal tribunals, those that are focused on a particular country (e.g. Lebanon, Sierra Leone, Rwanda, or the former Yugoslavia) are acceptable, but an International Criminal Court is not unless the United States has an ability to preclude prosecution of its nationals. In other words, this antinomy notes the conflict between a vision of international law and institutions in which all states participate as equal sovereigns, and a vision of exceptionalism by which the United States habitually reaches for policies and structures that it alone controls, or that applies generally to states but not to itself.

Such tendency toward exceptionalism arises from a confluence of factors. Perhaps the most important is America's history over the past century as a country untouched by sustained armed conflict on its soil, protected by vast oceans from any serious threat of invasion (the sense of shock from, and aggressive response to, the isolated attacks of September 11 demonstrate this

\footnotetext{
${ }^{12}$ Declaration on Principles of International Law Concerning Friendly Relations and Co-operation Among
} States in Accordance With the Charter of the United Nations, G.A. Res. 2625 (XXV), annex (Oct. 24, 1970). 
deeply felt sense of U.S. security). This history tends both to undermine arguments for why the United States must adhere to global norms and instruments, and to foster an instinct to avoid "entangling" alliances that might draw it into the conflicts of other states. There are many other factors, including the demise of the Soviet empire, which eliminated the one dominant threat to the United States; the U.S. emergence as the sole global superpower, capable of projecting considerable power through unilateral action rather than relying on cooperation with other states; the increasingly conservative U.S. political environment vis-à-vis other developed states (including the existence of a concentrated and active conservative minority that, as Andrew Moravscik has pointed out, has taken advantage of the fragmented nature of U.S. political institutions to resist implementation of international norms ${ }^{12}$ ); an indifference to the norms and institutions of other states due to a belief that American norms and institutions, over time, have proven superior to anything found abroad (i.e., the United States leads others, it does not follow them); a distinctive "rights culture" which emphasizes negative protections against government interference in private liberties, and does not emphasize, unlike other Western states and emerging democracies, activist provision by government of socio-economic and welfare rights (i.e., entitlements to food, health care, etc.); and important relatively recent demographic and cultural shifts that pull the United States away from even its traditional allies (i.e., the continuing and increasing role of Christian faith in the United States as compared with the secularization of Europe; the gradual "Islamicization" of Europe due to immigration, such that if Turkey joins the European Union there will be more Muslims than Protestants in Europe ${ }^{13}$ ).

This presence of exceptionalism in U.S. relations with the World Court has two important effects. First, exceptionalists are inherently unhappy with any international institution that can issue pronouncements regarding the legality of U.S. conduct. For exceptionalists, an international court may be a good thing for keeping other states in line, but the United States almost always does the right thing and, when it does not, any repercussions should flow from national legal and political institutions, not from abroad. Second, even when the ICJ is not

${ }^{12}$ See Andrew Moravcsik, The Paradox of U.S. Human Rights Policy, in American Exceptionalism and Human Rights 147 (Michael Ignatieff, ed. 2005).

${ }^{13}$ Niall Ferguson, The Widening Atlantic, The Atlantic, Jan./Feb. 2005, at 40. 
passing upon the legality of U.S. conduct, the exceptionalist is skeptical about the Court because it at times reaches conclusions that differ from those of the U.S. government, and therefore (for the exceptionalist) the Court is simply wrong.

\section{1.c. Autonomous National Law Versus National Law Embedded in International Law}

A third antinomy arises from the conflict between favoring a national legal system that is embedded in international law, as a means of ensuring U.S. adherence to and implementation of its international obligations, and disfavoring such incorporation to the extent that it transgresses national democratic and constitutional traditions that promote diffusion of power and governance of persons by their freely elected officials.

The United States at its founding saw adherence to international obligations as an important means of establishing the international legitimacy and security of a nascent republic, and so adopted constitutional and judicial principles that international law was a part of national law and superior to the law of the several states. The U.S. Constitution provides for treaties to be part of the "supreme law of the land" 14 and provides for the supremacy of federal law over state law. ${ }^{15}$ Further, the Supreme Court has been favorably disposed toward the incorporation of customary international law into U.S. law, ${ }^{16}$ and to its interpretation whenever possible so as to

\footnotetext{
${ }^{14}$ U.S. Const. art. VI, $\S 2$.

${ }^{15} I d$.

${ }^{16}$ See Ware v. Hylton, 3 Dall. 199, 281, 1 L.Ed. 568 (1796) (Wilson, J.) ("When the United States declared
} their independence, they were bound to receive the law of nations, in its modern state of purity and refinement."); The Nereide, 9 Cranch 388, 423, 3 L.Ed. 769 (1815) (Marshall, C.J.) ("[T]he Court is bound by the law of nations which is a part of the law of the land."); The Paquete Habana, 175 U.S. 677, 700 (1900) ("International law is part of our law, and must be ascertained and administered by the courts of justice of appropriate jurisdiction, as often as questions of right depending upon it are duly presented for their determination."); Banco Nacional de Cuba v. Sabbatino, 376 U.S. 398, 423 (1964) ("[I]t is, of course, true that United States courts apply international law as a part of our own in appropriate circumstances.”); Texas Industries, Inc. v. Radcliff Materials, Inc., 451 U.S. 630,641 (1981) (recognizing that "international disputes implicating . . . our relations with foreign nations" are one of the 
avoid conflicts with international law. ${ }^{17}$

At the same time, strong currents in the American constitutional and democratic tradition seek to keep international law at a distance, such as through the doctrine of non-self-executing treaties and the trumping of customary international law by later-in-time statutes or "controlling executive acts." 18 Further, from the beginning of its history, America has been proud of the manner in which it has divided power among the three branches of its federal government, and between the federal government and the several states. Such division of power was designed to promote a democratic but well-functioning government, and to preclude concentration of power in a single organ. While this constitutional tradition is a marvel, there can be little doubt that it has impeded the integration of the United States into the international legal system. Dividing power between the President and the Senate may have helped prevent the emergence of an American monarch in foreign policy, but it has also prevented presidents from embracing broadranging jurisdiction of a global court from the early twentieth century forward. Restraining the federal government from being able to regulate on certain matters of individual rights prevents a governmental denial of civil liberties, but places the United States in a difficult position internationally on matters such as regulating the freedom of speech of the tobacco industry or on matters of race. Dividing power between the federal government and the several states allows for greater local governance and numerous "laboratories" for developing laws, but it also makes it extraordinarily difficult for the United State to adhere to international norms that require greater national uniformity.

Consequently, there is an enduring schizophrenia in the U.S. constitutional and democratic tradition regarding the manner in which it incorporates international law, and this conflict is aggravated when the issue of courts is added to the picture. The United States has

\footnotetext{
"narrow areas" in which "federal common law" continues to exist); Sosa v. Alvarez-Machain, 542 U.S. 692, 729 (2004) ("For two centuries we have affirmed that the domestic law of the United States recognizes the law of nations.").

${ }^{17}$ See Murray v. The Charming Betsy, 2 Cranch 64, 118, 2 L.Ed. 208 (1804) (“[A]n act of Congress ought never to be construed to violate the law of nations, if any other possible construction remains."); Weinberger v. Rossi, 456 U.S. 25, 32 (1982) (the same).
} 
always accepted the importance and significance of a judiciary for the resolution of disputes; the importance and legacy of the Supreme Court from the early American republic to the present is ingrained in every American schoolchild. Yet the American democratic tradition strongly favors rule by the people principally through their popularly-elected officials, such that there is an enduring suspicion of judges (local, let alone foreign) whose decisions do not hew closely to the laws enacted by the people. By and large, Americans do not favor their judges undertaking teleological interpretations of law; to the extent that laws need to be adapted, they look to the legislatures to do it. U.S. judges have been activist at times, both for conservative and liberal causes, but the practice does not sit well with the American democratic tradition, and repeatedly evokes controversy. This conflict between a belief in an independent judiciary and distrust of activist judges explains in part the country's ambivalence to the International Court (as well as efforts in some quarters to prevent judges from applying in U.S. courts norms generated outside the United States, whether formed by customary international law, within treaty regimes, or otherwise).

As discussed in Part IV, this antinomy recently has presented the U.S. government with difficult issues regarding the relationship of International Court decisions to the conduct of the law enforcement officials and courts of the several U.S. states. ${ }^{19}$ Among other things, it has led to the acknowledgment that final judgments of the International Court are binding as a matter of international law, but to assertions by the Executive Branch that such judgments have no direct effect within the national legal system.

\section{Techniques for Mediating the Antinomies}

The World Court uses certain methods or mechanisms, formal or informal, to mediate the

18 The Paquete Habana, 175 U.S. at 700.

${ }^{19}$ See Andreas L. Paulus, From Neglect to Defiance? The United States and International Adjudication, 15 Eur. J. Int'l L. 783 (2004) ("The democratic tradition of the US, in which the government cannot rely on a majority in the legislature, sometimes stands in the way of the acceptance of rulings by 'unelected' international judges. Fifty state systems differ in their respect for international rulings.”) 
antinomies discussed above. Such techniques do not attempt to eliminate either of the conflicting principles captured by those antinomies; rather, the techniques take for granted the antinomies and seek to find a path between the conflicts presented. In essence, mediating techniques ${ }^{20}$ seek to play to tendencies of institutionalism, of sovereign equality, and of incorporation of international law into national law, while accepting that conflicting principles of realism/institutionalism, exceptionalism/sovereign equality, and autonomous national law/embedded national law circumscribe the role the Court may play. The discussion of such techniques below is combined with brief highlights of the history of the U.S. relationship with the International Court.

As is well-known, the predecessor to the International Court of Justice - the Permanent Court of International Justice (PCIJ) - was created in the aftermath of World War I. Caught up in the rising tide of institutionalism of the late nineteenth/early twentieth century, and believing that that reliance solely on international arbitration for resolution of inter-state disputes was not good enough, the United States became actively engaged in the negotiations that led to the establishment of the PCIJ. ${ }^{21}$ Though arbitration had a role to play, American international

${ }^{20}$ For discussions of such techniques, see W. Michael Reisman, Systems of Control in International Adjudication and Arbitration (1992); Laurence R. Helfer \& Anne-Marie Slaughter, Toward a Theory of Effective Supranational Adjudication, 107 Yale L.J. 273 (1997); Robert Adieh, Between Dialogue and Decree: International Review of National Courts, 79 N.Y.U. L. Rev. 2029 (2004); Laurence R. Helfer \& Anne-Marie Slaughter, Why States Create International Tribunals: A Response to Professors Posner and Yoo, Cal. L. Rev. (forthcoming 2005).

${ }^{21}$ U.S. interest in international arbitration dates from early in its history, see Janis, supra note 8, at 97-116, but that interest for more than 100 years was principally focused on disputes with its "mother country," the United Kingdom. The Treaty of Amity, Commerce and Navigation, Nov. 19, 1794, U.S.-U.K., 8 Stat. 116, T.S. No. 105 (commonly referred to as the "Jay Treaty" after U.S. Secretary of State John Jay), established three boards of arbitration to resolve disputes between the United Kingdom and its former colony. The Treaty of Washington, May 8, 1871, U.S.-U.K., 17 Stat. 863, T.S. No. 133, established four arbitrations for addressing Britain's conduct during the U.S. civil war, including Britain's responsibility for allowing the construction of the Confederate raider Alabama. See Tom Bingham, The Alabama Claims Arbitration, 54 Int'1 \& Comp. L.Q. 1 (2005). Other U.S./U.K. arbitrations addressed fur seals, the Venezuela-British Guiana boundary, and Alaska. In the years leading up to World War I, the United States entered into a few treaties providing for international arbitration, principally with Latin American states, but broader efforts foundered in the U.S. Senate. 
lawyers and policy-makers — such as Elihu Root — argued that it tended toward "an essentially political process of negotiation and compromise on the basis of expedience rather than the judicial procedure of impartial adjudication of rights and duties in strict accordance with the rules of law." 22 The latter process was an option that states should have, since judicial decisions, being grounded more firmly in a rigorous application of law by persons not selected by the disputants, could serve as a means for definitively and convincingly resolving certain kinds of disputes. The United States had pressed without success for the creation of such a court at the 1907 Hague peace conference; now, after the carnage of world war, other states were willing to go along.

As is also well-known, however, the U.S. Senate never consented to ratification of the Covenant of the League of Nations, nor of the separate protocol embodying the Statute of the PCIJ. While the PCIJ had its supporters in the United States, strong voices of realism and exceptionalism, particularly in the U.S. Senate, argued that submission to the jurisdiction of a world court would harm national interests, and would diminish or jeopardize national sovereignty. When put to a vote in 1935, adherence to the protocol secured 52 votes in favor and 36 against, thus falling seven votes short of a two-thirds majority. ${ }^{23}$ Throughout the life of the PCIJ from 1922 to 1945 — during which time the court issued 27 advisory opinions and 32 judgments ${ }^{24}$ - the United States never participated in any litigation before the court, although an

The other principal U.S. inter-state arbitration prior to World War II concerned Mexico. In September 1923, the United States and Mexico signed a convention in Washington D.C. (which took effect in March 1924) creating a General Claims Commission. The purpose of the commission was to settle claims arising after July 4, 1868, "against one government by nationals of the other for losses or damages suffered by such nationals or their properties" and "for losses or damages originating from acts of officials or others acting for either government and resulting in injustice." Composed of three members (from the U.S., from Mexico, and from a third country), the Commission met from 1924 to 1937 in Washington, D.C. and Mexico City. Final settlement was reached in 1941.

${ }^{22}$ See Francis Anthony Boyle, Foundations of World Order 37 (1999); see also Michael Dunne, The United States and the World Court, 1920-1935 at 17-46 (1988).

${ }^{23} 79$ Cong. Rec. 1147 (1935). For an account, see Denna Frank Fleming, The United States and the World Court: 1920-1966 at 117-137 (rev. ed. 1968).

${ }^{24}$ See Shabtai Rosenne, The World Court and How It Works 16 (5th ed. 1995). 
American judge always served on the Court. ${ }^{25}$ The substantive and procedural decisions of the PCIJ remain of interest today, since the Statute of the ICJ is essentially the same as that of its predecessor. Indeed, while states decided in the aftermath of World War II to create a new international court, they also decided to maintain continuity in its concept and function. ${ }^{26}$

Unlike the experience with the League, the United States joined the United Nations in 1945 and therefore ipso facto became a party to the ICJ statute. ${ }^{27}$ Institutionalists emphasized that the success of a new system of international organizations to maintain peace and security, one built upon the rule of law, necessarily entailed the creation of an international court. The U.S. delegation to the San Francisco conference reported to President Franklin D. Roosevelt that "[a]s the United States becomes a party to a Charter which places justice and international law among its foundation stones, it would naturally accept and use an international court to apply international law and to administer international justice." ${ }^{28}$ Testifying prior to the Senate's consent to ratification, the head of the U.S. delegation in San Francisco, Edward Stettinius, asserted that the Court will "have a most important part to play in the further development and strengthening of international law, just as the courts of England and America have helped to form the common law. ${ }^{29}$ The State Department Legal Adviser (and later first American judge on the new Court), testified that the United States historically stood for

"....the settlement of international cases by the judicial process; that we did try as far back as 1907 to establish a court; that such a court was established in 1922 and has

${ }^{25}$ The PCIJ judges of U.S. nationality were: John Bassett Moore (1922-28); Charles Evan Hughes (192830); Frank B. Kellogg (1930-35); and Manley O. Hudson (1936-42).

${ }^{26}$ See Amry Vandenbosch \& Willard N. Hogan, The United Nations: Background, Organization, Functions, Activities 190 (1952).

${ }^{27}$ See U.N. Charter art. 93.

${ }^{28}$ The Charter of the United Nations: Hearings before the Senate Committee on Foreign Relations, 79th Cong., 121 (1945) [hereinafter 1945 Senate Hearing] (report to the President on the Results of the San Francisco Conference, dated June 26, 1945).

${ }^{29}$ Id. at 219 (statement of Edward R. Stettinius, Jr., personal representative of the U.S. President to the San Francisco Conference). 
been functioning ever since, and that while we did not go into that Court, there was strong sentiment in this country, as you well know, for our becoming a party. Here we have provision for a Court, in the creation of which we have played an important part. Speaking for myself and for those who have been associated with me in this work, I think that we cannot too strongly urge ... that we have here provided for the creation of an International Court of Justice that will be worthy of the name, and one that will make a great contribution to the maintenance of international peace and security. The Court is not as spectacular as some of the other organizations provided for in the Charter, but we think that it will serve an extremely important purpose, and that an International Organization without such a Court would be lacking in a very important essential", ${ }^{0}$

The UN Charter and the Court, of course, had their realists and exceptionalists detractors; some argued among other things that adherence to the Charter would "make slaves of our free citizens," 31 and that the ICJ would unconstitutionally usurp the jurisdiction of the Supreme Court "over all foreign disputes of this Nation." 32 Notwithstanding such views, the Senate in 1945 gave consent to ratification of the Charter, by a vote of 89 to $2 .^{33}$

Even so, the United States did not embrace an international court that held wide-ranging and unconstrained authority. Structural aspects built into the Court sought to mediate between the desire of all states (including the United States) for an impartial, permanent judicial forum, and the desire of states to control their exposure to ICJ decision-making (and, when exposed, to have their concerns be fairly heard and understood).

\section{2.a. Only States, Not Persons}

\footnotetext{
${ }^{30}$ Id. at 344 (statement of Green H. Hackworth, U.S. Department of State Legal Adviser).

${ }^{31}$ Id. at 353 (statement of Mrs. Agnes Waters, legislative representative of the National Blue Star Mothers
} of America).

${ }^{32}$ Id. at 381 (statement of David Darrin, United Nations of Earth Association).

3391 Cong. Rec. 8190 (1945). 
At the time of the creation of the International Court, the idea that individuals might themselves pursue claims before an international tribunal was largely unknown. Consequently, the Statute of the Court provides that only states may appear before it in contentious cases, thus precluding voices that are not vested in the overall system of state sovereignty. This is an important design feature that provides states with a much greater comfort level regarding their exposure to the jurisdiction of the Court. Although today several states have accepted international courts that allow individuals to sue their own governments - such as the European Court of Human Rights - many others (including the United States) have been unwilling to do so. Were the International Court to have such jurisdiction, it would be a serious obstacle for U.S. participation, for it would invariably result in the Court passing upon matters that traditionally have been handled solely within the national legal system.

\section{2.b.- Circumscribed Jurisdiction}

The dominant structural aspect controlling a state's exposure to the ICJ is that states cannot be sued absent their consent. While there was considerable support at the San Francisco conference in favor of making the Court's jurisdiction compulsory, the United States and the Soviet Union were adamantly opposed. Faced with a deal-breaker, the other nations backed down. ${ }^{34}$ Consequently, under the Court's statute, consent to jurisdiction does not exist merely by virtue of a state being a party to the statute; separate express consent must exist. This requirement of state consent is why most of the $192 \mathrm{UN}$ member states have never appeared before the Court in a contentious case, and why the Court is regarded as an important but not dominant player in the field of international dispute resolution.

While consent is needed, the statute is structured so as to make giving such consent as easy as possible. First, states can accept the Court's jurisdiction on an ad hoc basis for the adjudication of an existing dispute. ${ }^{35}$ For example, the United States and Canada in 1981 jointly

\footnotetext{
${ }^{34}$ See Ruth B. Russell, A History of the United Nations Charter 884-90 (1958).

${ }^{35}$ Statute of the International Court of Justice art. 36(1), 59 Stat. 1055, 3 Bemis 1153 [hereinafter ICJ
} Statute]. 
agreed to bring to the Court a dispute over their maritime boundary. ${ }^{36}$ That case, however, was the last time the United States agreed to bring a dispute to the Court on an ad hoc basis. Instead, bilateral disputes that might have been addressed by the Court under its ad hoc jurisdiction have been dealt with through bilateral negotiation ${ }^{37}$ or through bilateral arbitration. ${ }^{38}$ The United States has also promoted ad hoc arbitration directly between injured nationals and foreign states by coercing foreign states into accepting such jurisdiction. ${ }^{39}$

Second, states can adhere to a bilateral or multilateral treaty that expressly provides for International Court jurisdiction when cases arise relating to the interpretation or application of the treaty. ${ }^{40}$ (Treaties pre-dating the existence of the ICJ that provide for jurisdiction of the PCIJ are also regarded, under the statute as triggering ICJ jurisdiction ${ }^{41}$ ). This form of jurisdiction is inherently limited, for the jurisdiction only arises from matters within the scope of the treaty. The narrower the scope of the treaty, the narrower the scope of the Court's jurisdiction. The breadth of the treaty may be addressed by including within it only a limited set of positive rights or obligations; it may also be addressed by clauses within the treaty that carve out issues, such as matters relating to national security.

Moreover, when ratifying a treaty providing for the World Court's jurisdiction over disputes, a state may be entitled to file a reservation to the provision on dispute resolution. For

${ }^{36}$ See Delimitation of the Maritime Boundary of the Gulf of Maine Area, 1984 ICJ 246 (Oct. 12).

${ }^{37}$ See, e.g., Treaty with Mexico on Delimitation of Continental Shelf, June 9, 2000, U.S.-Mex., S. Treaty Doc. No. 106-39 (2000).

${ }^{38}$ See, e.g., Heathrow Airport User Charges Arbitration, 102 I.L.R. 215 (1992) (involving dispute between the United States and the United Kingdom over airport user charges at Heathrow Airport).

39 See, e.g., Compañía del Desarrollo de Santa Elena S.A. v. Costa Rica ICSID Case No. ARB/96/1, Final Award (Feb. 17, 2000), reprinted in 15 ICSID Rev._Foreign Investment L.J. 169 (2000). Costa Rica agreed to submit this and other disputes with U.S. investors to arbitration after being threatened by the United States with a loss of international financing and a suspension of U.S. aid to Costa Rica pursuant to the 1994 “Helms Amendment.” See 22 U.S.C. \$2370a (2000).

\footnotetext{
${ }^{40}$ ICJ Statute, art. 36(1).

${ }^{41}$ Id., art. 37.
} 
example, the Genocide Convention ${ }^{42}$ sets forth various obligations of states with respect to preventing and punishing genocide, and it further provides that disputes arising under the convention between parties shall be submitted to the ICJ at the request of one of the parties. ${ }^{43}$ However, when the United States ratified the Genocide Convention in 1988, it stated that before any dispute could be submitted to the Court under Article IX, "the specific consent of the United States is required in each case." ${ }^{44}$ Consequently, when Yugoslavia in 1999 sought to sue the United States under the Genocide Convention (for acts associated with the intervention in Kosovo), the ICJ found that - in light of the American reservation - there was no jurisdiction and therefore dismissed the case. ${ }^{45}$

The United States is a party to many treaties that confer jurisdiction on the Court, enabling it to sue and be sued thereunder. ${ }^{46}$ In the wake of the Nicaragua decision (discussed below), there has been repeated discussion within the U.S. government of withdrawing from dispute resolution provisions under such treaties, but the technical and political difficulties of doing so have so far left most of those provisions intact.

The last case brought to the Court by the United States under this form of jurisdiction was by an application filed in 1987 in the ELSI case. ${ }^{47}$ In that case, the United States invoked a compromissory clause contained in a 1948 bilateral Treaty of Friendship, Commerce, and Navigation that provided for Court jurisdiction over disputes arising under that treaty. ${ }^{48}$ The U.S.

\footnotetext{
${ }^{42}$ Convention on the Prevention and Punishment of the Crime of Genocide, Dec. 9, 1948, 78 U.N.T.S. 277.

${ }^{43} I d$., art. IX.

${ }^{44}$ See 28 I.L.M. 782 (1989).

${ }^{45}$ See Legality of Use of Force (Yugo. v U.S.), 1999 ICJ 916 (June 2).

${ }^{46}$ See Table \# 1 at end of this volume.

${ }^{47}$ See Elettronica Sicula S.p.A. (ELSI) (U.S. v. Italy), 1989 ICJ 15 (judgment of July 20). While the United
} States technically "sued" Italy at the International Court, in fact the states agreed diplomatically in advance that the dispute would be brought before the International Court, although Italy maintained its right to raise issues of jurisdiction and admissibility of the matter. As noted below, the two states also agreed to request that the Court form a chamber of five judges specified by the parties, which the Court did.

${ }^{48}$ Treaty of Friendship, Commerce and Navigation, Feb. 2, 1948, U.S.-Italy, art. XXVI, 63 Stat. 2255, 79 U.N.T.S. 171. 
claim alleged expropriation of and interference with property of an American company's subsidiary in Sicily. The Court ultimately concluded that no harm had occurred from the alleged acts.

Since the ELSI case, the only other dispute pursued by the United States that might have led to the filing of an independent ${ }^{49}$ claim before the International Court appears to have been the "hushkits" dispute between the United States and Europe. On March 14, 2000, the United States initiated a dispute resolution proceeding by filing an application and memorial before the International Civil Aviation Organization (ICAO) Council in its capacity as a judicial body. ${ }^{50}$ The dispute concerned a European Union (EU) regulation adopted in 1999 relating to aircraft noise —one that imposed design-based restrictions on aircraft registered in, or operating into, Europe. In November 2000, the Council rejected certain preliminary objections raised by the European Union. ${ }^{51}$ In the aftermath of the ICAO Council decision, neither the United States nor EU member states exercised their right to appeal the Council's decision to the International Court of Justice, in accordance with the procedure set forth in the Chicago Convention. ${ }^{52}$ Rather,

${ }^{49}$ The United States did file a counter-claim based on a bilateral treaty of amity in the case brought by Iran for destruction of Iranian oil platforms in the Gulf. See Oil Platforms (Iran. v. U.S.), para. 9 (ICJ Nov. 6, 2003), 42 ILM 1334 (2003); see Pieter Bekker, Case Report: Oil Platforms (Iran v. United States), 98 Am. J. Int'l L. 550 (2004). The Court rejected that counter-claim.

${ }^{50}$ Such a dispute is brought under Article 84 of the Convention on International Civil Aviation, Dec. 7, 1944, 61 Stat. 1180, 15 U.N.T.S. 295 [hereinafter Chicago Convention], and Article 2 of the ICAO Rules for the Settlement of Differences, ICAO Doc. 7782/2 (2d ed. 1975).

${ }^{51}$ See Decision of the ICAO Council on the Preliminary Objections in the Matter "United States and 15 European States (2000)" (Nov. 16, 2000) (on file with author).

${ }^{52}$ See Chicago Convention, supra note 49, art. 84 ("Any contracting State may, subject to Article 85, appeal from the decision of the Council to an ad hoc tribunal . . . or to the Permanent Court of International Justice.") Article 85 clarifies the ambiguity of Article 84 by noting that an ad hoc arbitral tribunal is relied upon where a party to a dispute has not accepted the Statute of the Permanent Court of International Justice and the parties to the dispute cannot agree on the choice of the arbitral tribunal. While the Convention is not clear on whether a party to a dispute under Article 84 has the right to appeal an ICAO Council decision on jurisdiction, the International Court of Justice has decided that such appeal is possible. Appeal Relating to the Jurisdiction of the ICAO Council (India v. Pak.), 1972 ICJ 46, 60 (Aug. 18). 
the EU member states filed their counter-memorial in December 2000 and the parties thereafter settled the matter. ${ }^{53}$

Since the 1980's, the United States has consistently declined to accept or incorporate into treaties compromissory clauses calling for adjudication of disputes by the International Court of Justice. If the United States adheres to major multilateral treaties (such as the Genocide Convention) which contain such a clause, then the government typically files a reservation to that clause. If the United States adheres to major multilateral treaties that allow parties to opt for ICJ jurisdiction, then it declines to do so. Thus, should the United States ratify the 1982 U.N. Convention on the Law of the Sea, it has already announced that it will opt for compulsory arbitral dispute resolution, not resolution by the International Court. ${ }^{54}$ U.S. bilateral investment treaties (BITs) now invariably call for investor-state arbitration before the International Centre for the Settlement of Investment Disputes (ICSID) or another forum, ${ }^{55}$ a striking contrast to the earlier generation of treaties of Friendship, Commerce, and Navigation (FCN treaties), which

${ }^{53}$ See U.S. Dep't of State Press Release on US Withdrawal of Complaint at ICAO (June 13, 2002), at $<\mathrm{http}$ //www.state.gov/r/pa/prs/ps/2002/11096.htm>. This dispute was only the second in ICAO's history that was addressed by the ICAO Council in its judicial capacity, the first being the dispute between India and Pakistan almost 30 years ago, which was appealed to the Court. See Appeal Relating to the Jurisdiction of the ICAO Council (India v. Pak.), supra note 51.

${ }^{54}$ See U.S. Secretary of State Letter of Submittal to the President, in United Nations Convention on the Law of the Sea, With Annexes, and the Agreement Relating to the Implementation of Part XI of the United Nations Convention on the Law of the Sea, with Annex, S. Treaty Doc. 103-39, V at IX-X (1994); see also Testimony of U.S. Dep't of State Legal Adviser William H. Taft, IV Before the Senate Foreign Relations Committee (Oct. 21, 2003), $a t$ $<$ http://www.state.gov/g/oes/rls/rm/2003/25573.htm>.

55 See, e.g., Treaty Concerning the Encouragement and Reciprocal Protection of Investment, Oct. 25, 2004, U.S.-Uruguay, §B, at < http://www.ustr.gov/Trade_Agreements/Bilateral/Section_Index.html $>$. The current "model”" bilateral investment treaty of the United States — upon which the U.S.-Uruguay agreement noted above was basedprovides for disputes to be submitted to arbitration under ICSID or under the UNICTRAL rules, or to another arbitral forum agreed upon by the parties. See Treaty Between the Government of the United States of America and the Government of Concerning the Encouragement and Reciprocal Protection of Investment, art. 24 (Nov. 2004), at <http://www.state.gov/documents/organization/38710.pdf>. 
provided for ICJ jurisdiction over state-to-state disputes. Investment disputes arising under the North American Free Trade Agreement (NAFTA) are also sent to investor-state arbitration before ICSID $^{56}$ or an ad hoc panel operating under the UNCITRAL rules. ${ }^{57}$ U.S. trade disputes - under agreements completed in the past fifteen years - are placed before World Trade Organization (WTO) panels, ${ }^{58}$ panels operating under NAFTA Chapter $19^{59}$ or $20,{ }^{60}$ or panels operating under bilateral trade agreements; ${ }^{61}$ they are not submitted to the International Court.

Third, under what is known as the "optional clause," the states parties to the ICJ Statute may by means of a unilateral declaration undertake that "they recognize as compulsory ipso facto and without special agreement, in relation to any other state accepting the same obligation, the jurisdiction of the Court in all legal disputes ..." involving issues of law or fact governed by rules of international law. ${ }^{62}$ In 1946, the United States accepted the Court's compulsory jurisdiction, hoping that doing so would encourage other states to follow suit. ${ }^{63}$ At the same time,

${ }^{56}$ See, e.g., Waste Mgmt., Inc. v. Mexico, Award, para. 98 (NAFTA Ch. 11 Arb. Trib. Apr. 30, 2004), reprinted in 43 ILM 967 (2004).

${ }^{57}$ See, e.g., GAMI Investments, Inc. v. Mexico, Final Award (NAFTA Ch. 11 Arb. Trib. Nov. 15, 2004).

${ }^{58}$ See, e.g., Canada-Measures Affecting the Importation of Milk and the Exportation of Dairy Products, WTO Doc. WT/DS103/AB/RW2, WT/DS113/AB/RW2 (Dec. 12, 2002); Japan-Measures Affecting the Importation of Apples, WTO Doc. WT/DS245/AB/R (Nov. 26, 2003); Canada-Measures Relating to Exports of Wheat and Treatment of Imported Grain, WTO Doc. WT/DS276/R (Apr. 6, 2004); Canada-Measures Relating to Exports of Wheat and Treatment of Imported Grain, WTO Doc. WT/DS276/AB/R (Aug. 30, 2004).

${ }^{59}$ See, e.g., Corrosion-Resistant Carbon Steel Flat Products from Canada, Full Sunset Review (NAFTA Ch. 19 Panel Oct. 19, 2004).

${ }^{60}$ See, e.g., Cross-border Trucking Services (NAFTA Ch. 20 Arb. Trib. Feb. 6, 2001).

${ }^{61}$ See, e.g., Free Trade Agreement, June 15, 2004, U.S.-Morocco, Ch. 20, at $<\mathrm{http} / / /$ www.ustr.gov/Trade_Agreements/Bilateral/Section_Index.html $>$.

${ }^{62}$ See ICJ Statute, art. 36(2); see also M. Fitzmaurice, The Optional Clause System and the Law of Treaties: Issues of Interpretation in Recent Jurisprudence of the International Court of Justice, 20 Austl. Y.I.L. 127 (1999); J.G. Merrills, The Optional Clause Revisited, 64 Brit. Y.B. Int'l L. 197 (1993).

${ }^{63}$ See U.S. Declaration Accepting the Compulsory Jurisdiction of the International Court of Justice (Aug. 26, 1946). At the time the U.S. declaration was submitted, Herschel V. Johnson, Acting U.S. Representative to the United Nations, asserted:

"One of the most elemental functions of the United Nations in the preservation of world peace is 
it placed in its declaration certain reservations, including the so-called "Connally reservation" (or "amendment") which excluded from the jurisdiction of the Court "disputes with regard to matters which are essentially within the domestic jurisdiction of the United States of America as determined by the United States of America" (emphasis added). The purpose of this "selfjudging" clause was to ensure that the U. S. government and not the Court's judges would decide, as a practical matter, whether a dispute is "domestic" in character and consequently outside the Court's jurisdiction. Since such a reservation in essence forecloses the ability of the Court to decide whether it has jurisdiction in a case, ${ }^{64}$ many scholars and some ICJ judges have expressed doubts as to whether such a reservation is permissible, ${ }^{65}$ but to date the Court has not definitively addressed the issue.

Early in the life of the Court, the Connally reservation proved to be a double-edged sword. Since the Court operates on a principle of reciprocity in application of its compulsory jurisdiction, ${ }^{66}$ the reservation had the effect of entitling any state the United States wished to sue to invoke the reservation against the United States. When the United States sued Bulgaria in 1957 for an attack on an El Al aircraft flying over Bulgarian territory (resulting, among other

the development of procedures of pacific settlement. In these procedures, the role and functions of law is clear. We feel that international law is already sufficiently developed to serve as a guide and basis in international relations. We feel further that the best way of assuring its further development, and the only way of enabling it to fulfill its function, is by referring to a responsible international tribunal all disputes properly justiciable by such a tribunal."

See 15 State Dep't Bull. 452 (Sept. 1, 1946). For Senate consideration, see Compulsory Jurisdiction, International Court of Justice: Hearings Before a Subcommittee of the Senate Committee on Foreign Relations on S. Res. 196, 79th Cong., 2d Sess. (1946); see also S. Rep. No. 1835, 79th Cong., 2d Sess. (1946) (report of the Senate Foreign Relations Committee).

${ }^{64}$ See ICJ Statute, art. 36(6).

${ }^{65}$ See Interhandel Case (Switz. v. U.S.), 1959 ICJ 6, 95 (Mar. 21) (separate opinion of Judge Lauterpacht); Military and Paramilitary Activities in and against Nicaragua (Nicar. v. U.S.), 1984 ICJ 392, 601-02 (Nov. 26) (dissenting opinion of Judge Schwebel); Fisheries Jurisdiction (Spain v. Can.), 1998 ICJ 432, 575 (Dec. 4) (dissenting opinion of Judge Vereshchetin).

${ }^{66}$ See ICJ Statute, art. 36(2) (allowing states to file declarations accepting compulsory jurisdiction "in relation to any other state accepting the same obligation"). 
things, in the death of six American nationals), Bulgaria responded that the matter was "essentially within" Bulgaria's "domestic jurisdiction," and thus outside the jurisdiction of the Court. The United States at first objected that such a response was in bad faith, but ultimately concluded that allowing the Court to decide whether it was in bad faith would defeat the entire point of the reservation, and so withdrew its case. ${ }^{67}$

While in theory the Connally reservation could be invoked at will, the United States declined to do so in the case brought by Nicaragua in 1984, no doubt because it simply was not credible to declare that American attacks allegedly occurring in Nicaraguan territory were matters "essentially within the domestic jurisdiction of the United States." When the Court rejected other jurisdictional objections raised by the United States in the Nicaragua case, ${ }^{68}$ in October 1985 the U.S. government announced that it was terminating its declaration accepting compulsory jurisdiction, in accordance with the terms of the U.S. declaration. ${ }^{69}$ The termination became effective in 1986 and remains so today.

The reasons stated for terminating the declaration fell broadly into four areas. ${ }^{70}$ First, the United States was clearly upset at the Court for finding that jurisdiction existed over Nicaragua's case, which resulted in the judges wading into the highly-charged politics of President Reagan's Latin American policy. For the U.S. government, the Court's decision that Nicaragua had accepted the Court's compulsory jurisdiction, that El Salvador could not intervene at the

${ }^{67}$ See Leo Gross, Bulgaria Invokes the Connally Amendment, 56 Am. J. Int'1 L. 357 (1962).

${ }^{68}$ See Military and Paramilitary Activities in and against Nicaragua (Nicar. v. U.S.), 1984 ICJ 392 (Nov. 26).

${ }^{69}$ See United States: Department of State Letter and Statement concerning Termination of Acceptance of ICJ Compulsory Jurisdiction, 24 I.L.M. 1742 (1985). A year earlier, in an effort to forestall the Nicaragua case, the United States attempted to modify its declaration so as to exclude "disputes with any Central American state." 84 Dep't of State Bull. 89 (June 1984). The United States also declined to participate in the ensuing merits phase of the Nicaragua case, which led to a judgment against the United States on several counts. See Military and Paramilitary Activities in and against Nicaragua (Nicar. v. U.S.), 1986 ICJ 14 (June 27). Thereafter, the United States ignored the Court's judgment and, as noted below, vetoed measures of implementation sought by Nicaragua at the Security Council.

${ }^{70}$ See Testimony of Abraham D. Sofaer, U.S. Dep't of State Legal Adviser, to the Senate Foreign Relations 
jurisdiction stage, and that Nicaragua's claims were justiciable, simply could not be correct as a matter of law. Second, the United States asserted that the benefits anticipated from accepting the Court's compulsory jurisdiction had not materialized. Originally, the United States accepted the Court's compulsory jurisdiction in the hope that other states would follow, but most states had not done so, including China and the Soviet Union. Further, most of the cases that had advanced to the merits were not based on the Court's compulsory jurisdiction, and therefore such jurisdiction had not become a principal part of the Court's overall jurisprudence. The United States itself had tried seven times to sue a state before the ICJ on the basis of compulsory jurisdiction, but had never been successful in doing so. ${ }^{71}$ Third, the United States emphasized the costs of adherence to the Court's compulsory jurisdiction. Three states had sued the United States on the basis of such jurisdiction. ${ }^{72}$ Besides, other states could undertake "hit-and-run" tactics, by waiting until they wished to sue the United States before filing a declaration accepting the Court's compulsory jurisdiction, and then after filing the case, withdrawing that declaration to avoid being sued. Finally, the United States attacked the credibility and impartiality of the judges of the Court, noting that most came from states that had not accepted the Court's compulsory jurisdiction. Moreover, since the judges must be elected by the General Assembly, and since the majority of states in the Assembly did not, and still do not, share the U.S. view on important international questions (including the special position of the permanent members of the Security Council in maintaining international peace and security), "[o]ne reasonably may expect at least some of the judges to be sensitive to the impact of their decisions on their standing with the U.N. majority." ${ }^{73}$ Be that as it may, arguably the withdrawal of the acceptance of the

Committee (Dec. 4, 1985), reprinted in 86 Dep't of State Bull. 67 (Jan. 1986) [hereinafter Sofaer Testimony].

${ }^{71}$ See infra note 107.

${ }^{72}$ Rights of Nationals of the United States in Morocco (Fr. v. U.S.), 1952 ICJ 176 (Aug. 27); Interhandel (Switz. v. U.S.), 1959 ICJ 6 (Mar. 21); Military and Paramilitary Activities in and against Nicaragua (Nicar. v. U.S.), 1986 ICJ 14 (June 27).

${ }^{73}$ Sofaer Testimony, supra note 70 , at 69 . Thomas Franck responded to the charge of bias against the United States by noting that: (1) of the 115 judgments and advisory opinions issued between 1948 and 1985, the U.S. judge voted with the majority 82 times, and dissented in whole or in part only 15 times; (2) an examination of the dissents reveals that the U.S. judge disagreed with the majority "in circumstances that often fail to confirm the 
Court's compulsory jurisdiction was, from the start, of little practical import, given the nature, scope, and effect of the Connally reservation.

While the termination of this acceptance of the Court's compulsory jurisdiction may be unfortunate, the United States is in good company. The only permanent member of the Security Council that currently accepts the Court's compulsory jurisdiction is the United Kingdom; China, France, and Russia do not. Further, the United Kingdom's acceptance is conditioned by several significant reservations that make it quite difficult to sue it before the Court. Moreover, the vast majority of states have not accepted the Court's compulsory jurisdiction. Of 192 member states of the United Nations, only 65 have accepted the Court's compulsory jurisdiction as of January $2005^{74}$, and many of those acceptances contain significant conditions and reservations. $^{75}$

\section{2.c. State Influence on Selection of Judges}

Once exposed to ICJ decision-making, other structural aspects help assure states that their concerns will be fairly heard and understood. One such structural aspect is the manner in which judges are elected to the court. On the one hand, the de jure procedure entails a concurrent election of judges by the two principal organs of the United Nations (the General Assembly and the Security Council) ${ }^{76}$ based on the independence, character, and expertise of persons, and not on their nationality. ${ }^{77}$ While judges are precluded from participating in cases in which they were previously involved (which, sometimes, can have the effect of preventing judges from sitting in some cases involving their own states), ${ }^{78}$ there is no absolute bar to a judge sitting in a case

contention of bias"; and (3) "[i]n none of these cases could the majority be said to have taken a position that was contrary in any way to the U.S. national interest.” See Thomas M. Franck, Judging the World Court 37 (1986).

\section{${ }^{74}$ See Table \# 2 at end of this volume.}

${ }^{75}$ See John R. Crook, The International Court of Justice and Human Rights, 1 Nw. U. J. Int'1 Hum. Rts. 2 ฯ 19 (2004).

\footnotetext{
${ }^{76}$ ICJ Statute, arts. 4(1) \& 8.

${ }^{77} I d$., art. 2.

${ }^{78} I d$., art. 17(2).
} 
involving a state of the judge's nationality. ${ }^{79}$ The judges serve for nine-year terms and cannot be recalled or dismissed by the government of their nationalities during their tenure.

On the other hand, the procedure for selection of judges is not blind to nationality. No two judges on the court may be of the same nationality. ${ }^{80}$ The judges are to be selected so that the principal legal systems of the world are represented ${ }^{81}$ and, as an informal matter, the seats of the judges on the Court are allocated according to regional quotas. ${ }^{82}$ In contentious cases, if a party has no judge of its nationality sitting on the court, it may appoint an ad hoc judge to sit in the case. ${ }^{83}$ Further, while the permanent members of the Security Council do not have a "veto" with respect to the election of ICJ judges (a simple majority of eight votes is required), ${ }^{84}$ the five permanent members are in a position to influence strongly the process. It should be no surprise that they have always had one of their nationals on the Court's bench. ${ }^{85}$

Having a judge of the state's nationality (or the state's region), of course, does not guarantee a decision in the state's favor. Cases are decided by majority of the whole bench. No "veto" power is accorded to judges from particular states. Moreover, some (but not all) studies indicate that historically judges have not automatically sided with their state of nationality. ${ }^{86}$

${ }^{79} I d$., art. 31(1).

${ }^{80} I d$., art. 3(1).

${ }^{81} I d$., art. 9.

${ }^{82}$ I The Charter of the United Nations: A Commentary 1162 (Bruno Simma ed. 2d ed. 2002)..

${ }^{83}$ ICJ Statute, art. 31(2) \& (3).

${ }^{84}$ Id., art. 10; see I The Charter of the United Nations: A Commentary, op. cit, at 482 . Normally voting by the Security Council requires a majority of nine.

${ }^{85}$ A judge from each of the permanent members has been on the Court since its inception, with the exception of a gap between 1967 and 1985 when there was no Chinese judge. II The Charter of the United Nations: A Commentary, supra note 81, at 1161.The ICJ judges of U.S. nationality to date have been: Green Hackworth (1946-61); Philip Jessup (1961-70); Hardy Cross Dilliard (1970-79); Richard Baxter (1979-80); Stephen Schwebel (1981-2000); and Thomas Buergenthal (2000-present).

${ }^{86}$ See Edith Brown Weiss, Judicial Independence and Impartiality: A Preliminary Inquiry, in Crossroads, supra note 8,123 at 134 (finding that "the record does not reveal significant alignments, either on regional, political, or economic basis. There is a high degree of consensus among the judges on most decisions."); see also Dinah Shelton, Legal Norms to Promote the Independence and Accountability of International Tribunals, 2 Law \& Prac. 
Even so, the Statute provides a means for two contending states to move the center of gravity of the Court closer to their value systems. Article 26 of the Statute allows the Court to establish a chamber (i.e. a small sub-group of the whole bench) of judges to decide a case. The Court typically is inclined to do so, if both parties request it and identify the judges they wish appointed to such a chamber. Moreover, unlike under the Statute of the PCIJ, the chamber does not need to represent "the principal legal systems of the world;" just certain regions. Thus, in the Gulf of Maine case, Canada and the United States informed the Court that they wished a chamber formed consisting of five judges identified by the parties. ${ }^{88}$ In the ELSI case, Italy and the United States informed the Court that they too wished to have a chamber consisting of five specific judges. ${ }^{89}$ In both cases, the states were clearly interested in having greater control over the legal and political attitudes being brought to the judicial table, and in both cases the Court played along. Despite this nod toward party control, the judgments of the chambers are technically ${ }^{90}$ and in practice, regarded as judgments of the Court as a whole.

In addition to jurisdiction over contentious cases between two states, the Court also has jurisdiction to issue advisory opinions on legal questions. The advisory jurisdiction may be invoked only by U.N. organs and by some of the specialized agencies of the United Nations and the opinions, by definition, are non-binding. Nevertheless, advisory opinions have juridical authority; they can serve to legitimate certain conduct of states and organizations, and invariably have significance for a legal system in which judicial precedents are scarce. In practice, advisory

Int'l Cts. \& Tribunals 27, 32 (2003); but see Eric A. Posner \& Miguel de Figueiredo, Is the International Court of Justice Politically Biased? (unpublished draft dated Oct. 2004);Eric Posner, The Decline of the International Court of Justice (unpublished draft) (finding that ICJ judges do not apply the law impartially but favor the interests of their home states or like-minded states).

${ }^{87}$ See PCIJ Statute, art. 9. For background, see Stephen M. Schwebel, Ad Hoc Chambers of the International Court of Justice, 81 Am. J. Int'1 L. 831 (1987).

${ }^{88}$ See Delimitation of the Maritime Boundary of the Gulf of Maine Area, 1982 ICJ 3 (order of Jan. 20); see also Davis Robinson, David Colson, \& Bruce Rashkow, Some Perspectives on Adjudicating Before the World Court: The Gulf of Maine Case, 79 U.N. 578 (1985).

${ }^{89}$ See Elettronica Sicula S.p.A. (ELSI) (U.S. v. Italy), 1987 ICJ 3 (order of Mar. 2).

${ }^{90}$ ICJ Statute, art. 27. 
opinions are relied upon and cited as legal authority as frequently as judgments rendered in contentious cases.

\section{2.d. No Direct Enforcement of Judgments In National Law}

International tribunals differ markedly in the manner in which their decisions are "embedded" in the national systems of the states that are subject to the tribunal's jurisdiction. ${ }^{91}$ Agreements creating international tribunals can make decisions directly enforceable in a national legal system, without any need for governments to take post-hoc implementing action (e.g., through statutes or executive orders). This, too, is a technique for mediating between conflicting visions of what the tribunal should be.

In the spirit of institutionalism, ICJ judgments in contentious cases are binding on the parties, final, and without appeal. ${ }^{92}$ Further, by the UN Charter, each U.N. member "undertakes to comply with the decision of the International Court of Justice in any case to which it is a party." $" 93$ Yet, when drafting the U.N. Charter and the ICJ Statute, states elected not to include any provisions addressing the legal effect of ICJ judgments within national legal systems, such as whether they provide a basis for private rights of action in national courts. Seen from the U.S. point of view, this is consistent with autonomous democratic and constitutional traditions. Moreover, as a concession to exceptionalism, the U.N. Charter provides that a party that prevailed before the Court may to submit non-compliance with the ruling to the scrutiny of the U.N. Security Council, "which may, if it deems necessary, make recommendations or decide upon measures to be taken to give effect to the judgment." 94 Of all the cases decided on the merits in the Court's history, in only one did an applicant - Nicaragua - request that the Security Council take action to enforce the judgment. Needless to say, the United States vetoed a

${ }^{91}$ See, e.g., Robert O. Keohane et al., Legalized Dispute Resolution: Interstate and Transnational, 54 Int'1 Org. 457, 458 (2000).

\footnotetext{
92 See ICJ Statute, Arts. 59-60.

${ }^{93}$ U.N. Charter, art. 94(1).

${ }^{94}$ Id., art. 94(2).
} 
resolution to that effect. ${ }^{95}$ An effort by private individuals to sue the U.S. government in U.S. courts based, among other things, on the ground that U.S. actions violated the Court's decision, was dismissed because there is no private right of action to enforce an International Court decision in U.S. courts. ${ }^{96}$

\section{2.e. Discursive and Political Constraints}

Besides formal or quasi-formal techniques, there are also certain political constraints that operate to mediate the antinomies. ${ }^{97}$ The Court knows that its legitimacy and credibility as an institution rest not only on the objective correctness of its legal reasoning, but on the acceptance of that legal reasoning by international lawyers, and more broadly by the global community of states.

Arguably "judicial law-making that consistently results in the loss of dispute settlement cases by a powerful member (as both a complainant and a respondent) would not be sustainable politically, for it would constitute a shift in property rights that would likely engender a political reaction." $" 98$ As U.S. Supreme Court Justice Felix Frankfurter once wrote with respect to the U.S. Supreme Court:

“...the Court's authority - possessed of neither the purse nor the swordultimately rests on sustained public confidence in its moral sanction. Such feeling must be nourished by the Court's complete detachment, in fact and in appearance, from political

${ }^{95}$ See 25 I.L.M. 1337, 1352-65 (1986); see also Constanze Schulte, Compliance with Decisions of the International Court of Justice 199-205 (2004); Colter Paulson, Compliance with Final Judgments of the International Court of Justice Since 1987, 98 Amer. J. Int'1 L. 434 (2004).

${ }^{96}$ See Comm. of U.S. Citizens Living in Nicaragua v. Reagan, 859 F.2d 929 (1988).

${ }^{97}$ For a discussion regarding how a tribunal operates within a "strategic space" that is bounded not just by formal constraints, but by informal constraints that are both "discursive" and "political" in nature, see Richard H. Steinberg, Judicial Lawmaking at the WTO: Discursive, Constitutional, and Political Constraints, 98 Am. J. Int'l L. 247 (2004).

${ }^{98} I d$. at 268-69. 
33

entanglements and by abstention from injecting itself into the clash of political forces in political settlements. " 99

The International Court is unlikely to issue a decision that, though perhaps regarded by its judges as soundly based in law, is regarded by international lawyers generally as misguided, or by the global community at large as politically unacceptable. Were it to do so, its viability could be severely impaired. Instead, it strives to issue decisions that are likely to be wellreceived within the international legal community and by its primary constituents: states. By doing so, it helps encourage states to submit cases, which in turn justifies its own significance and importance.

To a certain extent, this mediating technique has operated in the context of "admissibility" doctrines. Even if the Court finds that it has jurisdiction over a case, sometimes the Court has refused to pass upon the merits of the case. In doing so, the Court spares itself coming into conflict with certain aspects of the antimonies discussed above. For example, in certain cases it has relied upon the rule of customary international law known as the "local remedies rule" as a means of respecting decision-making by states within their national systems. Under the rule, before a state may espouse a claim on behalf of its national, it must be shown that the latter has exhausted all available legal remedies in the courts and before the administrative agencies of the state against which the claim is brought. In 1959, the United States successfully avoided suit before the ICJ by invoking this rule, ${ }^{100}$ in doing so, the Court in effect accepted that resolution of a dispute, at least in the first instance, should be left to U.S. courts. In another case where the United States was the claimant, it successfully proved to the Court that the rule was satisfied. ${ }^{101}$ In theory, the rule aims to permit states to remedy wrongs at the national level before they become a dispute on the international plane, where it might disrupt unnecessarily international relations. In practice, however, it also provides the Court with an opportunity to decline to pass upon a dispute that could place it in direct conflict with the tendency of some states toward strong constitutional autonomy. Similarly, the Court at times has seized upon

\footnotetext{
${ }^{99}$ Baker v. Carr, 369 U.S. 186, 267 (1962) (dissenting opinion of Justice Frankfurter).

${ }^{100}$ See Interhandel Case (Switz. v. U.S.), 1959 ICJ 6 (Mar. 21).

${ }^{101}$ See Elettronica Sicula S.p.A. (ELSI) (U.S. v. Italy), 1989 ICJ 15 (judgment of July 20).
} 
34

doctrines of standing ${ }^{102}$ and mootness ${ }^{103}$ to avoid passing upon highly-charged disputes.

Even if a case reaches the merits phase, it is possible to detect judicial reasoning that reflects sensitivity to the political limits of the Court's authority. In the Nuclear Weapons advisory opinion, the Court engaged in a systematic analysis of why treaties and customary rules of international law did not prohibit the possession or use of nuclear weapons, and then why certain principles of international humanitarian law did prohibit such use. The Court, however, could not quite bring itself to declare nuclear weapons unlawful in all circumstances. No doubt several of the judges were sensitive to the fact that nuclear weapons were unlikely to be eliminated because of a decision by the Court, and that the most powerful states in the world rejected the idea that the possession and use of such weapons were in all circumstances unlawful. Further, the judges were no doubt conscious that a decision to that effect was not firmly grounded in international law; there were certainly no treaties that expressly stated as much and the application of principles of international humanitarian law was plausible but not obvious. Consequently, the final conclusion reached was that the use of nuclear weapons as a general matter was unlawful, but that, in certain extreme circumstances involving the very survival of a state, such use might be lawful. Although this conclusion is problematic as a matter of legal analysis, it was a politically shrewd move by the Court, giving to the anti-nuclear movement strong language against the legality of nuclear weapons, while allowing powerful states a basis for maintaining the status quo.

\section{A Look at U.S. Cases Before the ICJ}

\section{3.a. The Overall Track Record}

Out of a total 105 contentious cases filed before the Court from 1946 to 2004, the United States was involved in twenty-one. ${ }^{104}$. No other state has appeared before the Court so frequently. Moreover, other major powers such as China and Russia have never appeared before

${ }^{102}$ South West Africa (Ethiopia v. S. Afr.; Liberia v. S. Afr.), 1966 ICJ 6 (July 18).

${ }^{103}$ Nuclear Tests (Austr. v. Fr.; New Zealand v. Fr.), 1974 ICJ 253 (Dec. 20).

${ }^{104}$ See Table \# 3 at end of this volume. 
the Court in a contentious case.

In ten of the twenty-one cases, the United States was the applicant (or jointly agreed to the submission of the case to the Court), and the United States:
- $\quad$ secured a boundary decision regarded by many as favorable to the U.S. position; $^{105}$

- $\quad$ won one on the merits; ${ }^{106}$

- $\quad$ lost one on the merits; ${ }^{107}$

- $\quad$ had to withdraw or accept removal of seven cases against Soviet bloc states due to lack of jurisdiction. ${ }^{108}$

In eleven cases, the United States was the respondent, and:

- two were settled or withdrawn prior to a decision on the merits by the Court, $^{109}$

- three were dismissed by the Court on jurisdictional or admissibility

${ }^{105}$ See Delimitation of the Maritime Boundary of the Gulf of Maine Area, 1984 ICJ 246 (judgment of Oct. 12).

${ }^{106}$ United States Diplomatic and Consular Staff in Tehran (U.S. v. Iran), 1980 ICJ 3 (judgment of May 24). Although this judgment was in the United States favor, the Court concluded its decision by chastising the United States for its failed effort to rescue the hostages in April 1980 (involving the death of eight U.S. soldiers), which the United States undertook from a belief that "the situation in Iran posed mounting dangers to the safety of the hostages ...." Id., para. 32. The Court informed the United States that the operation was "of a kind calculated to undermine respect for the judicial process in international relations." Id., para. 93.

${ }^{107}$ See Elettronica Sicula S.p.A. (ELSI) (U.S. v. Italy), 1989 ICJ 15 (judgment of July 20).

${ }^{108}$ Aerial Incident of 27 July 1955 (U.S. v. Bulgaria), 1960 ICJ 146 (order of May 30); Aerial Incident of 7 November 1954 (U.S. v. U.S.S.R.), 1959 ICJ 276 (order of Oct. 7); Aerial Incident of 4 September 1954 (U.S. v. U.S.S.R.), 1958 ICJ 158 (order of Dec. 9); Aerial Incident of 10 March 1953 (U.S. v. Czech.), 1956 ICJ 6 (order of Mar. 14); Aerial Incident of 7 October 1952 (U.S. v. U.S.S.R.), 1956 ICJ 9 (order of Mar. 14); Treatment in Hungary of Aircraft and Crew of the United States of America (U.S. v. Hungary), 1954 ICJ 99 (order of July 12); Treatment in Hungary of Aircraft and Crew of the United States of America (U.S. v. U.S.S.R.), 1954 ICJ 103 (order of July 12).

${ }^{109}$ See Aerial Incident of 3 July 1988 (Iran v. U.S.), 1996 ICJ 9 (Feb. 22) (ordering discontinuance of the case following a settlement); Questions of Interpretation and Application Arising from the Aerial Incident at Lockerbie (Libya v. U.S.), 2003 ICJ 152 (Order of Sept. 10) (ordering discontinuance of the case). 
grounds, ${ }^{110}$

- $\quad$ one was won on the merits, ${ }^{111}$

- $\quad$ one was partially won and partially lost on the merits; ${ }^{112}$

- four were lost on the merits. ${ }^{113}$

Of the cases lost on the merits, none was taken to a damages phase, so the existence of a monetary judgment against the United States has not arisen.

As for whether it is possible to detect any trends looking at these cases chronologically, there might be said to be four periods:

\begin{tabular}{|c|c|}
\hline $\begin{array}{l}\text { High hopes } \\
(1950-1959)\end{array}$ & $\begin{array}{l}\text { Several efforts by the United States to invoke the jurisdiction of the Court, } \\
\text { without success; at the same time, success in avoiding the Court's } \\
\text { jurisdiction. }\end{array}$ \\
\hline $\begin{array}{l}\text { Benign neglect } \\
(1960-1979)\end{array}$ & Lengthy period viewing the Court as either a failure or as inconsequential. \\
\hline $\begin{array}{l}\text { Re-engagement } \\
\text { and rejection } \\
(1980-87)\end{array}$ & $\begin{array}{l}\text { Return to the Court to handle both a territorial dispute and a major political } \\
\text { crisis; bitter rejection of the Court after losing a politically-charged Cold } \\
\text { War case. }\end{array}$ \\
\hline
\end{tabular}

${ }^{110}$ See Legality of Use of Force (Yugo. v U.S.), 1999 ICJ 916 (June 2); Interhandel (Switz. v. U.S.), 1959 ICJ 6 (Mar. 21); Monetary Gold, 1954 ICJ 19 (June 15).

${ }^{111}$ Oil Platforms (Iran. v. U.S.) (ICJ Nov. 6, 2003), 42 ILM 1334 (2003). At the same time, the Court in the Platforms case, as discussed below, engaged in an extensive analysis on why the U.S. use of force could not be justified as a matter of international law.

${ }^{112}$ Rights of Nationals of the United States in Morocco (Fr. v. U.S.), 1952 ICJ 176 (Aug. 27).

${ }^{113}$ Military and Paramilitary Activities in and against Nicaragua (Nicar. v. U.S.), 1986 ICJ 14 (June 27); Vienna Convention on Consular Relations (Para. v. U.S.), Provisional Measures, 1998 ICJ 11 (Order of Apr. 9), reprinted in 37 ILM 810 (1998) (this case only reached the provisional measures stage, where the United States lost); LaGrand Case (Ger. v. U.S.), 2001 ICJ 466 (June 27), reprinted in 40 I.L.M. 1069 (2001); Avena and Other Mexican Nationals (Mex. v. U.S.), Judgment (Mar. 31, 2004), 43 ILM 581 (2004). In most of these cases, the United States prevailed on certain arguments before the Court that at least narrowed the scope of the Court's findings. 


\begin{tabular}{|l|l|l}
$\begin{array}{l}\text { Playing defense } \\
\text { (1988-present) }\end{array}$ & $\begin{array}{l}\text { Declining to bring any cases; aggressively defending against cases brought } \\
\text { by others; resisting the Court without breaking from it; a turn to other fora } \\
\text { (WTO; NAFTA; ICSID; UNCLOS arbitration) }\end{array}$ \\
\hline
\end{tabular}

In addition to the Court's contentious jurisdiction, from 1946 to 2005, the International Court of Justice issued 24 advisory opinions. The United States was involved in 22 of those advisory opinions either in the form of written or oral pleadings. ${ }^{114}$ Again, no other state has participated in advisory proceedings so frequently. It is harder to see any discernible trends in this practice, although it appears that the United States was more enthusiastic about using the Court's advisory opinion jurisdiction early in the life of the Court, when it had greater influence in the General Assembly. In more recent years (e.g., the Nuclear Weapons advisory opinion; the Israeli Wall advisory opinion), the United States has opposed the asking of certain questions to the Court and, once asked, has argued that the Court should decline to answer the question.

\section{3.b. Recent Cases}

\section{3.b.I. Oil Platforms case}

The realism/institutionalism antinomy is evident in the recent Oil Platforms case. The institutionalism strain in U.S. thinking resulted in the acceptance of a compromissory clause in the 1955 U.S.-Iran Treaty of Amity, providing for ICJ jurisdiction over disputes arising under that treaty. ${ }^{115}$ At the same time, the realism strain sought to avoid application of international law and international dispute resolution to core national interests, thus resulting in the inclusion of a clause stating that the Treaty of Amity "shall not preclude the application of measures . . . necessary to protect ... essential security interests." 116 Iran - a state weaker than the United States in terms of military and economic power - used the Court to challenge the deployment of

${ }^{114}$ See Table \# 4 at end of this volume.

${ }^{115}$ See Treaty of Amity, Economic Relations and Consular Rights, U.S.-Iran, Aug. 15, 1955, art. XX(1)(2), 8 U.S.T. 899, 284 U.N.T.S. 93.

${ }^{116} I d$., art. $\mathrm{XX}(1)(\mathrm{d})$. 
U.S. power in the Persian Gulf, specifically U.S. attacks against Iranian oil installations in 198788. After the filing of Iran's 1992 application initiating the case, American realism might have led the United States to simply ignore it; to decline to participate in proceedings, where it had no comparative advantage vis-à-vis Iran, and where it was politically vulnerable to adverse findings. Yet the early 1990's was period of resurgent institutionalism in the United States. Institutionalist landmarks of this period, which would not have been possible without proactive U.S. engagement, were the extraordinary multilateralism of the U.N.-authorized action against Iraq, the operation in Somalia, and the creation of new tribunals such as the U.N. Compensation Commission, as well as the war crimes tribunals for the former Yugoslavia and Rwanda.

Thus, consistent with the spirit of that remarkable age, the United States elected to participate in the proceedings, and ultimately pursued a strategy with realism and institutionalism prongs. The realism prong emphasized that states had not given the Court plenary jurisdiction over disputes; that the Court's jurisdiction only extended so far as states had consented; and that, in this case, the United States had not consented to review of its military operations through the vehicle of a largely commercial treaty. The United States succeeded on most of these points, successfully winnowing Iran's claims down to a single treaty provision concerning freedom of commerce between the two states ${ }^{117}$ and convincing the bench that such commerce was not disrupted by the attacks on the oil platforms. ${ }^{118}$

At the same time, the United States had an institutionalist prong to its case. Arguing that the actions it took were necessary to protect "essential security interests" (and thus outside the scope of the treaty), the United States in essence sought to convince the Court that the attacks on Iranian oil platforms were legitimate self-defense. This prong held out hope that the Court would serve as an impartial arbiter of complicated facts and would acknowledge the rights of even a powerful state to defend itself, without an eye to the invasion of Iraq unfolding at the same time as oral hearings in the case. On this prong, the United States failed. Even though the Court found that the United States had not violated the Treaty of Amity by interrupting bilateral commerce with Iran, it had engaged in an extensive analysis of why the attacks on the oil platforms violated international law on the use of force, an analysis questioned thereafter by the U.S. Department of

\footnotetext{
${ }^{117}$ Id., art. X(1); see Oil Platforms (Iran. v. U.S.), 1996 ICJ 803 (judgment on preliminary objections).

${ }^{118}$ See Oil Platforms (Iran. v. U.S.), paras. 98-99 (ICJ Nov. 6, 2003), 42 ILM 1334, 1367-68 (2003)
} 
State Legal Adviser. ${ }^{119}$

In the Oil Platforms judgment, the Court neglected resorting to one of the mediating techniques available to address the realism/institutionalism antimony. The Court's willingness to address the legality of the use of force by the United States even though the Court had no jurisdiction over the case is a "pushing back" against the realist approach of denying the Court plenary jurisdiction. While such action, or reaction, by the Court may be understandable, there may be collateral consequences.

First, the judgment exposes the Court to arguments that it was not acting as an impartial decision-maker, but was set on lecturing the United States at a time when use of military force in Iraq in 2003 was being harshly criticized. ${ }^{120}$ Further, the fact that the "essential security interests" clause failed to insulate the United States from the Court casts into doubt the efficacy of such provisions in a myriad of existing treaties providing for ICJ jurisdiction, and will encourage the U.S. government to periodically consider whether and how it might withdraw from or modify such treaties to avoid litigation. ${ }^{121}$ Certainly, the cost/benefit analysis of this particular Treaty of Amity strongly suggests that it should be terminated: the United States has engaged in little economic activity and no consular activity with Iran for twenty-five years, ${ }^{122}$ yet it is exposed at any time to suit by Iran under the treaty's compromissory clause. Moreover, many in the U.S. government will perceive the Court's willingness to lecture the United States as confirmation that compromissory clauses providing for the Court's jurisdiction should not be

119 See William H. Taft IV, Self-Defense and the Oil Platforms Decision, 29 Yale J. Int'1 L. 295 (2004). The article identifies the author as Legal Adviser, U.S. Department of State, and contains no disclaimer that the views are personal.

120 See, e.g., David H. Small, The Oil Platforms Case: Jurisdiction through the-Closed-Eye of the Needle, 3 L. \& Prac. Int'l Courts \& Tribunals 113 (2004) (critique by OECD director of legal affairs, in his personal capacity).

${ }^{121}$ As noted in the next section, the United States in March 2005 terminated its acceptance of the Court's jurisdiction over matters arising under the Vienna Convention on Consular Relations.

122 There do remain U.S. diplomatic and consular properties in Iran, although they are principally protected under other treaties. Arguably the United States benefited from the Treaty of Amity when private U.S. claims were being adjudicated before the Iran-U.S. Claims Tribunal, since the Tribunal's decisions on occasion referred to certain standards set forth in the treaty. All U.S. private claims before the Tribunal, however, have now been 
included in new treaties. Finally, the ultimate effect of the decision is probably to foreclose any possibility of U.S. adherence to the Court's compulsory jurisdiction. If there is no way to carve out national security interests without inviting the judges to engage in an extended discussion of the underlying matter, even in situations where the United States ultimately succeeds in avoiding the Court's jurisdiction, then many will conclude that the U.S. has no business at the Peace Palace.

\section{3.b.ii. Israeli Wall Advisory Opinion}

The United States' tendency toward exceptionalism may be seen in its attitude toward the recent advisory opinion on the legality of the barrier by Israel in the occupied West Bank of the Jordan River. On December 8, 2003, the General Assembly adopted a resolution asking the ICJ for an advisory opinion on "the legal consequences arising from the construction of the wall being built by Israel, the occupying Power, in the Occupied Palestinian Territory, including in and around East Jerusalem . ..."123 The resolution received 90 votes in favor, 74 abstentions, and 8 opposed (including the United States). In opposing the resolution, the U.S. representative stated:

"The international community has long recognized that resolution of the [IsraeliPalestinian] conflict must be through negotiated settlement, as called for in Security Council resolutions 242 (1967) and 338 (1973). That was spelled out clearly to the parties in the terms of reference of the Madrid Peace Conference of 1991. Involving the International Court of Justice in this conflict is inconsistent with that approach and could actually delay a two-State solution and negatively impact road map implementation. Furthermore, referral of this issue to the International Court of Justice risks politicizing the Court. It will not advance the Court's ability to contribute to global security, nor will it advance the prospects of peace". ${ }^{124}$

resolved.

${ }^{123}$ GA Res. ES-10/14 (Dec. 12, 2003).

${ }^{124}$ U.N.Doc. A/ES-10/PV.23, at 19 (Dec. 8, 2003). 
The United States instead favored pursuing the "Quartet's road map"- a plan that the United States, the European Union, the Russian Federation, and the U.N. Secretary-General developed in 2003 to further the process (initiated at the 1991 Madrid Conference) for peacefully resolving the Israeli-Palestinian conflict. ${ }^{125}$ Thus, the United States was committed to an approach for the Israeli-Palestinian conflict entailing diplomacy by a restricted group of powers, not by the international community at large. The United States opposed submitting this matter to the World Court because doing so could intrude upon the unique ability of the major powers to influence and shape the peace process.

Of course, in its written pleadings to the Court the United States did not advance legal arguments predicated on exceptionalism, for there was no legal basis for doing so. Instead, it sought to take advantage of some of the mediating techniques referred to above. It argued that the Court should decline to answer the question of grounds of judicial propriety because the question was not an abstract enquiry, but, in essence, a bilateral dispute in disguise. ${ }^{126}$ The United States hoped to convince the judges that they would be stepping over the bounds of the structural constraints on the Court's jurisdiction if they were to pass upon a dispute when the relevant parties to that dispute had not consented to jurisdiction. Implicit in this argument was a further argument that it was improper to decide a bilateral dispute between two parties when one of the parties had not yet even been recognized by the United Nations as a sovereign state (a decision in part controlled by the Security Council), and, therefore, could not appear before the Court. Further, the United States stressed that it was not for the Court to address an issue that was more properly addressed through political negotiations. ${ }^{127}$

\footnotetext{
${ }^{125}$ See Letter Dated 7 May 2003 from the Secretary-General Addressed to the President of the Security Council, annex, U.N.Doc. S/2003/529 (May 7, 2003) (containing “A Performance-Based Road Map to a Permanent Two-State Solution to the Israeli-Palestinian Conflict").

126 Written Statement of the United States of America, paras. 3.3-3.10 (filed Jan. 30, 2004), Legal Consequences of the Construction of a Wall in the Occupied Palestinian Territory, Advisory Opinion (ICJ July 9, 2004). The United States made no oral submissions to the Court.

${ }^{127}$ Id., para. 4.6 ("Any expression of legal views by the Court on the permanent status issues can be expected to make the necessary political accommodations between the parties on these issues far more difficult or even impossible.")
} 
Ultimately, the Court determined that answering the question would not impede the Middle East peace process. That conclusion was no doubt shared by a majority of states represented in the General Assembly, as was the Court's conclusion on the merits that Israel was violating international law by constructing the barrier. Yet, from the perspective of American exceptionalism, the majority of states can very well be wrong about whether it is a good idea to involve the Court in this issue, and also misguided more generally in their opposition to Israeli policies. The Court's attitude in the advisory opinion may well reflect the dominant views of policy-makers in other countries, but for the exceptionalist, that does not mean the Court is right.

\section{3.b.iii. Breard/LaGrand/Avena cases}

The recent cases concerning the treatment of aliens on death row in the United States highlights the antinomy created by the American democratic and constitutional tradition. The crux of the Breard/LaGrand/Avena line of cases is that aliens arrested by law-enforcement officials often have not been advised of their right to have their consulate notified of their arrest, something states party to the Vienna Convention on Consular Relations (Vienna Convention) have agreed to do. ${ }^{128}$ Some aliens, thereafter, have been convicted of serious crimes and sentenced to death. Paraguay, Germany, and Mexico each brought a case against the United States before the ICJ by invoking the Optional Protocol Concerning Compulsory Settlement of Disputes to the Vienna Convention on Consular Relations. ${ }^{129}$ In each instance, the applicant asked the Court to indicate provisional measures of protection, namely that the individuals would not be executed prior to a decision by the Court on the merits. Germany and Mexico also asked the Court for decisions on the merits regarding whether the United States had violated its obligations under the Vienna Convention and what consequences should flow from those violations. The United States has fully participated (when permitted) in all aspects of these cases before the Court, presenting extensive written and oral pleadings.

The U.S. reaction to the Breard/LaGrand/Avena line of cases may be considered in terms of both the Court's provisional orders and the decisions on the merits. In all three cases, the

\footnotetext{
${ }^{128}$ Apr. 24, 1963, art. 36, 21 U.S.T. 77, 101, 596 U.N.T.S. 261, 292.

${ }^{129}$ Apr. 24, 1963, 21 U.S.T. 325, 596 U.N.T.S. 487.
} 
Court issued an order on provisional measures that the United States "take all measures at its disposal to ensure" (Breard, LaGrand) or "all measures necessary to ensure" (Avena) that the relevant aliens not be executed pending a final decision by the Court. ${ }^{130}$ Prior to the Court's final judgment in the LaGrand case, the U.S. government argued both to the ICJ and to U.S. courts that such an order on provisional measures was not legally binding, and further that it had no direct effect in the U.S. legal system. Such a position has realism overtones, but the dominant feature appears to have been a concern to preserve the constitutional autonomy of the several states, and a political concern with intruding upon the democratic decision by those states to use the death penalty in their penal processes. Weighing that concern against the reality that the American constitutional system does incorporate international law, the U.S. government looked for credible legal arguments for why the Court's decision was not binding and not a part of U.S. law. Thus, after the first provisional measures order was issued on April 9, 1998 in the Breard case, the U.S. Department of Justice filed a brief before the U.S. Supreme Court stating that:

"The better reasoned position is that such an order is not binding. Article 41(1) of the ICJ statute provides that the ICJ shall have "the power to indicate any provisional measures which ought to be taken to preserve the respective rights of either power." Article 41(2) further states that, "[p]ending the final decision [of the ICJ], notice of the measures suggested shall forthwith be given to the parties and the Security Council." The use of precatory language ("indicate," "ought to be taken," "suggested") instead of stronger language (e.g.: the ICJ may "order" provisional measures that "shall” be taken) strongly supports a conclusion that ICJ provisional measures are not binding on the parties. The distinction in Article 41(2) between the "final decision" ultimately foreseen and the "measures suggested" in the interim also suggests that the "measures suggested" are not binding.

${ }^{130}$ Vienna Convention on Consular Relations (Para. v. U.S.), Provisional Measures, 1998 ICJ 11 (Order of Apr. 9), reprinted in 37 ILM 810, 819 (1998); Vienna Convention on Consular Relations (F.R.G. v. U.S.), Provisional Measures, 1999 ICJ 9 (Order of Mar. 3), reprinted in 38 ILM 308, 310 (1999); Avena and Other Mexican Nationals (Mex. v. U.S.), Provisional Measures (Feb. 5, 2003), reprinted in 42 ILM 309, para. 59 (2003); see William Aceves, Case Report, 97 Am. J. Int'1 L. 923 (2003). 
Petitioners have relied on the United Nations Charter to argue that provisional measures are binding, but the language of the Charter does not support that conclusion. Article 94(1) provides that "[e]ach member . . undertakes to comply with the decision of the [ICJ] in any case to which it is a party." (Emphasis added.) "The decision," in the context of Article 94(1) of the Charter, evidently refers to the final decision of the International Court. Article 94(2) of the Charter elaborates that "[i]f any party to a case fails to perform the obligations incumbent upon it by a judgment rendered by the [ICJ], the other party may have recourse to the Security Council." (Emphasis added.) Significantly, the Security Council has never acted to enforce provisional measures indicated by the ICJ. See Restatement [Third on the Foreign Relations Law of the United States], at 368 (discussing Security Council's response to ICJ's order indicating provisional measures in dispute between United Kingdom and Iran).

Moreover, the ICJ itself has never concluded that provisional measures are binding on the parties to a dispute. That court has indicated provisional measures in seven other cases of which we are aware; in most of those cases, the order indicating provisional measures was not regarded as binding by the respondent. ${ }^{131}$

In addition to these representations to the U.S. Supreme Court, the U.S. Secretary of State sent a letter to the Governor of Virginia requesting that he stay the execution of Breard since the "execution of Mr. Breard in the face of the Courț's April 9 action could be seen as a denial by the United States of the significance of international law and the Court's processes in its international relations and thereby limit our ability to ensure that Americans are protected when living or traveling abroad." 132 Here, again, may be seen a balancing act, in which the State Department sought to uphold U.S. adherence to international law and institutions, while respecting the constitutional autonomy of Virginia.

${ }^{131}$ Brief for the United States as Amicus Curiae at 46-51, Breard v. Greene, 523 U.S. 371 (1998) (Nos. $97-$ 1390, 97-8214) (footnote omitted).

${ }^{132}$ Letter from Madeleine K. Albright, U.S. Secretary of State, to James S. Gilmore III, Governor of Virginia (Apr. 13, 1998), partially reprinted in 92 Am. J. Int'l L. 671-72 (1998). 
45

The Supreme Court denied the petitions for certiorari that had been filed in the case. ${ }^{133}$ It did not focus on the binding nature of the ICJ's provisional measures order. Rather, it said that it was "clear that Breard procedurally defaulted his claim, if any, under the Vienna Convention by failing to raise that claim in the state courts." ${ }^{134}$ Further, the Court stated:

"[W]hile we should give respectful consideration to the interpretation of an international treaty rendered by an international court with jurisdiction to interpret such, it has been recognized in international law that, absent a clear and express statement to the contrary, the procedural rules of the forum State govern the implementation of the treaty in that State. . . . This proposition is embodied in the Vienna Convention itself, which provides that the rights expressed in the Convention "shall be exercised in conformity with the laws and regulations of the receiving State," provided that "said laws and regulations must enable full effect to be given to the purposes for which the rights accorded under this Article are intended." Article 36(2), 21 U.S. T., at 101. . .

Second, although treaties are recognized by our Constitution as the supreme law of the land, that status is no less true of provisions of the Constitution itself, to which rules of procedural default apply. We have held "that an Act of Congress . . is on a full parity with a treaty, and that when a statute which is subsequent in time is inconsistent with a treaty, the statute to the extent of conflict renders the treaty null." Reid v. Covert, 354 U.S. 1, 18 (1957) (plurality opinion) ... . The Vienna Convention-which arguably confers on an individual the right to consular assistance following arrest-has continuously been in effect since 1969. But in 1996, before Breard filed his habeas petition raising claims under the Vienna Convention, Congress enacted the Antiterrorism and Effective Death Penalty Act (AEDPA), which provides that a habeas petitioner alleging that he is held in violation of "treaties of the United States" will, as a general rule, not be afforded an evidentiary hearing if he "has failed to develop the factual basis of [the] claim in State court proceedings." 28 U.S.C. $\$ 2254(a)$, (e)(2) [(2000])."135

\footnotetext{
${ }^{133}$ Breard v. Greene, 523 U.S. 371 (1998).

${ }^{134} I d$. at 373 .

${ }^{135} I d$.
} 
After the Supreme Court denied the petitions for certiorari, the Governor of Virginia decided not to stay the execution, and Breard was executed.

The World Court's order on provisional measures in the LaGrand case was issued on March 3, 1999, at 7 p.m. (Hague time) without having heard the views of the U.S. government. ${ }^{136}$ In the late afternoon of March 3, the U.S. government transmitted the order to the Governor of Arizona. Just before the scheduled execution, Germany filed a case before the U.S. Supreme Court against the United States and Arizona seeking a temporary restraining order or preliminary injunction to enforce the order of the ICJ. The U.S. Solicitor General filed a letter opposing any stay, asserting that the "Vienna Convention does not furnish a basis for this Court to grant a stay of execution," and that "an order of the International Court of Justice indicating provisional measures is not binding and does not furnish a basis for judicial relief." In declining to exercise its original jurisdiction (with two justices dissenting), the Supreme Court explained in part:

"[A] foreign government's ability here to assert a claim against a State [i.e., Arizona] is without evident support in the Vienna Convention and in probable contravention of the Eleventh Amendment [to the U.S. Constitution] principles. This action was filed within only two hours of a scheduled execution that was ordered on January 15, 1999, based upon a sentence imposed by Arizona in 1984, about which the Federal Republic of Germany learned in 1992. Given the tardiness of the pleas and the jurisdictional barriers they implicate, we decline to exercise our original jurisdiction ". ${ }^{137}$

In dissent, Justices Breyer and Stevens said that they favored a stay of the execution to

136 The International Court's order was, for the first time, based wholly on the views of one party, without providing the opportunity to receive the views of the other party (here the United States) in writing or by oral hearing. The Court characterized its order as based on Article 75(1) of the Rules of the Court, which permits the Court to examine proprio motu (by its own motion) whether provisional measures should be ordered, although in fact there had been a request by Germany for such measures.

${ }^{137}$ Germany v. United States, 526 U.S. 111, 112 (1999). 
give more time to brief fully "the jurisdictional and international legal issues involved."138 The Governor of Arizona decided not to stay. Walter LaGrand was executed on March 4, 1999. ${ }^{139}$

While the executions in Breard and LaGrand in the face of the ICJ's order on the surface may suggest a complete U.S. disregard for the views of the Court, the United States took seriously the issue of whether it was bound by such orders, and reached an entirely plausible conclusion that they did not. Yet the animating feature of the American position was the problem presented by federal-state relations. Criminal justice in the United States is a matter almost entirely left to the several states; persons committing crimes in this country are typically tried under state laws and often in state courts. Further, whether to adopt the death penalty is a matter left to each state; some have elected to include the death penalty as a possible sanction whereas others have abolished or never had it. Those laws are adopted by the peoples of the states, through enactments by elected state legislators. The decision to convict a violent criminal and to impose the death penalty is a matter decided by the local community in form of an indictment by a grand jury, and a conviction and sentencing by a jury of the offender's peers. For the federal government to intrude upon that process by declaring that an execution must be stayed due to the decision of a court consisting almost entirely of foreigners residing an ocean away would have been an extraordinary and deeply unpopular undertaking by any administration, Democratic or Republican.

Despite the executions in Breard and LaGrand, the U.S. government embarked on an aggressive campaign to educate and train state law enforcement officers regarding obligations arising under the Vienna Convention, to the point of printing cards that officers were to carry with them and read out when arresting an alien. ${ }^{140}$ Moreover, after the Court held, in its judgment on the merits of the LaGrand case ${ }^{141}$, that provisional measures orders were binding,

${ }^{138}$ Id. at $112-13$.

${ }^{139}$ See World Court's Effort to Stay Execution Fails, Wash. Post, Mar. 4, 1999, at A16.

140 See U.S. Dep't of State, Consular Notification and Access, at $<$ http://travel.state.gov/law/consular/consular_636.html>; see also LaGrand (Ger. v. U.S.), 2001 ICJ 466, at para. 121, 123-24 (June 27), reprinted in 40 ILM 1069 (2001); Verbatim Record (Jan. 21, 2003), Avena and Other Mexican Nationals (Mex. v. U.S.), Provisional Measures, ICJ Doc. CR 2003/2, paras. 3.13-3.22.

${ }^{141}$ LaGrand Case (Ger. v. U.S.), Judgment, 2001 ICJ 466 (June 27), reprinted in 40 I.L.M. 1069 (2001); see William J. Aceves, Case Report, 96 Am. J. Int'l L. 210 (2002). 
and the further provisional measures order was issued in the Avena case, ${ }^{142}$ the United States did not publicly reject the Avena measures. Rather, it sought to implement them, albeit with extraordinary difficulty, principally by encouraging the commutation of death sentences of the relevant convicts by governors or parole boards. ${ }^{143}$

One of the central problems for the federal government in these cases concerned the "procedural default rule," a rule designed to help limit federal court review of state court decisions. In brief, under the procedural default rule, state law procedural rulings that are both sufficiently independent from federal law and adequate to sustain the judgment against the defendant ("procedural defaults") often preclude consideration of the merits of federal legal claims. Thus, if a defendant fails to file in state court proceedings a timely motion for a new trial or sentencing proceeding because he was not informed of his right to request consular notification, that procedural failure may bar filing such a motion not only thereafter before that state's courts, but also before federal courts.

Turning to the judgments in LaGrand and Avena, ${ }^{144}$ the Court found that the United States had violated its obligations under the Vienna Convention by not informing the aliens of their right of consular notification, by not notifying their consulates of their detentions, and by effectively depriving the consulates of the ability to communicate with and have access to the aliens. In both cases, the Court also found that the failure to provide judicial review of the aliens' convictions and sentences in light of the lack of notification constituted a further violation of the Vienna Convention. As for what the United States must do prospectively, in LaGrand the Court stated that, "should nationals of the Federal Republic of Germany nonetheless be sentenced to severe penalties", without their right to consular notification having been respected, the United States, "by means of its own choosing, shall allow the review and reconsideration of the conviction and sentence by taking account of the violation of the rights set forth" in the Vienna

${ }^{142}$ Avena (Provisional Measures), supra note 125, at para. 59.

${ }^{143}$ See Counter-Memorial of the United States, paras. 5.6-5.9 (Nov. 3, 2003), Avena and Other Mexican Nationals (Mex. v. U.S.), Judgment (Mar. 31, 2004).

144 Avena and Other Mexican Nationals (Mex. v. U.S.), Judgment (Mar. 31, 2004), reprinted in 43 ILM 581 (2004); see Dinah L. Shelton, Case Report, 98 Am. J. Int'l L. 559 (2004). 
49

Convention. ${ }^{145}$ The Court reached a similar finding on "review and reconsideration" with respect to the some fifty Mexican nationals at issue in the Avena case. ${ }^{146}$ As to how such "review and reconsideration" should occur, the International Court found in both LaGrand and Avena that a procedural default rule cannot justify precluding review of a petitioner's claim. ${ }^{147}$ Further, the Court found in both cases that Article 36 of the Vienna Convention creates "individual rights," which arguably means rights enforceable in U.S. courts. ${ }^{148}$ Apparently with an eye to the U.S. approach of relying on governors and parole boards to commute death sentences in light of the Vienna Convention violations, the Court in Avena also stated that the process must entail "a procedure which guarantees that full weight is given to the violations of the rights set forth in the Vienna Convention" and "should occur within the overall judicial proceedings relating to the individual defendant concerned." 149 The Court specifically noted that "the clemency process, as currently practised within the United States criminal justice system, does not appear to meet the requirements." 150

The initial fall-out from the decisions on the merits in LaGrand and Avena is a story of the federal government encouraging the various states to take into account the decisions of the International Court, without actually telling the states that they must do so as a matter of federal law. Not surprisingly, different courts went in different directions. In Madej v. Schomig, a federal district court found that the LaGrand judgment on the merits foreclosed strict reliance by U.S. courts on the procedural default rule for violations of the Vienna Convention. ${ }^{151}$ In Torres $v$. Oklahoma, a concurring state court judge found that the state court was bound by the Vienna

${ }^{145}$ LaGrand (Judgment), supra note 136, para. 128(7).

${ }^{146}$ Avena (Judgment), supra note 139, para. 153(9).

${ }^{147}$ LaGrand (Judgment), supra note 136, paras. 90-91; Avena (Judgment), supra note 139, paras. 110-13, 153.

${ }^{148}$ What the Court actually said was "Article 36, paragraph 1, creates individual rights, which, by virtue of Article I of the Optional Protocol, may be invoked in this Court by the national State of the detained person." LaGrand (Judgment), supra note 136, para. 77.

149 Avena (Judgment), supra note 139, paras. 139-40.

${ }^{150} I d$., para. 143.

${ }^{151}$ Madej v. Schomig, 223 F.Supp.2d 968 (N.D. Ill. 2002). 
Convention Optional Protocol to abide by the International Court's Avena decision. ${ }^{152}$ At the same time, a state court in Cauthern v. Tennessee concluded that, notwithstanding the International Court's judgments, the Vienna Convention does not create an individual right that is privately enforceable in the United States, nor that violations of the Vienna Convention may be raised as part of a petition for post-conviction relief. ${ }^{153}$ Similarly, in Medellin v. Dretke, the Fifth Circuit found that the Supreme Court's order denying certiorari in the Breard case supported application of the procedural default rule regardless of what the International Court said in its LaGrand and Avena judgments, and further that the Vienna Convention did not create an individual right that is privately enforceable. ${ }^{154}$

In December 2004, the Supreme Court granted a writ of certiorari in the Medellin case. The U.S. government filed in February 2005 an amicus brief urging the Court to affirm the Court of Appeals. Playing strongly to the vision of democratic and constitutional autonomy, the government argued that Article 36 of the Vienna Convention does not provide a basis for private judicial enforcement in U.S. courts. The government supported this position through an analysis of the language and structure of the Convention, read in context, its ratification history, and state practice, as well as the long-standing position of the Executive Branch. ${ }^{155}$ While the International Court's position might imply a right of private judicial enforcement in U.S. courts, the government asserted: "While the ICJ's understanding of the Convention's requirements is entitled to respectful consideration, it is ultimately the responsibility of this [U.S. Supreme] Court to interpret the meaning of a federal treaty." 156 The government also argued that the

152 Torres v. Oklahoma, No. PCD-04-442, slip. op. at 2-5, 8-12 (Okla. Crim. App. May 13, 2004) (Chapel, J., concurring) (footnotes omitted), reprinted in 43 ILM 1227 (2004).

${ }^{153}$ Cauthern v. Tennessee, 145 S.W.3d 571 (Tenn. Crim. App. 2004); see also United States v. MinjaresAlvarez, 264 F.3d 980 (10 ${ }^{\text {th }}$ Cir. 2001); State v. Issa, 93 Ohio St. 3d 49 (2001) (according little value to the LaGrand judgment); see generally Christopher J. Le Mon, Post-Avena Application of the Vienna Convention on Consular Relations by United States Courts, 18 Leiden J. Int'l L. 215 (2005).

${ }^{154}$ Medellin v. Dretke, 371 F.3d 270 (5th Cir. 2004). For a similar result before the Fifth Circuit in a different case, see Plata v. Dretke, 2004 WL 1814089 (5th Cir. Aug. 16, 2004).

${ }^{155}$ See Brief for the United States as Amicus Curiae Supporting Respondent, Medellin v. Dretke, No. 045928, at 18-30 (U.S.) (filed February 28, 2005).

${ }^{156} I d$., at 30 . 
Convention does not preclude application by U.S. courts of the procedural default rule. The government stated that the International Court was simply wrong when it found otherwise.

"[T]he ICJ in LaGrand concluded that applying procedural default to bar consideration of a challenge to a defendant's conviction and sentence violates [Vienna Convention] Article 36(2)'s requirement that laws of the forum state "must enable full effect to be given to the purposes for which the rights accorded under this Article are intended." But a general "full effect" clause cannot be understood to override application of rules that are as deeply embedded in the criminal justice system as rules of procedural default. ... [W]hile the ICJ's interpretation of Article 36(2) is entitled to respectful consideration, it does not provide a basis for the [U.S. Supreme] Court to overrule its controlling decision in Breard". 157

As for whether the International Court's decision in the Avena judgment could itself be privately enforced in U.S. courts, the government argued that it could not. The arguments were: (1) while the United States adhered to the Optional Protocol to the Vienna Convention, that protocol operates only to grant jurisdiction to the International Court over Vienna Convention disputes - it does not commit the United States to comply with the ICJ's judgment, nor make the judgment privately enforceable in a criminal proceeding by an individual; (2) rather, U.S. compliance with ICJ judgments is addressed in the U.N. Charter, which creates an international duty upon the United States to comply with the judgment, ${ }^{158}$ but does not make the ICJ judgment privately enforceable in court; (3) the mechanism for taking non-compliance before the U.N. Security Council confirms that ICJ judgments were not meant to be privately enforceable; (4) the U.S. ratification history confirms this interpretation, as does the one U.S. court decision that has addressed the matter; (5) the ICJ Statute states that ICJ judgments have no binding effect except between the parties in the case, thus negating the possibility of private judicial enforcement; and (6) the International Court itself stated that the U.S. obligation was to provide, by means of its

${ }^{157} I d$. at 31,33 .

158 The U.S. government interpreted the "judgment" of the International Court to apply only to the dispositif, not to the Court's legal reasoning. Id., at 38-39, n. 12. 
own choosing, review and reconsideration, which means that the U.S. political branches are entitled to pursue the matter by a choice of their means. ${ }^{159}$

Despite this strong statement in favor of autonomy, the government accepted that it had an international obligation to abide by the International Court's judgment and, further, decided that it had to do something about that obligation vis-à-vis the several states. Accordingly, President Bush on February 28, 2005, issued a memorandum to the Attorney General stating:

"The United States is a party to the Vienna Convention on Consular Relations (the "Convention") and the Convention's Optional Protocol Concerning the Compulsory Settlement of Disputes (Optional Protocol), which gives the International Court of Justice (ICJ) jurisdiction to decide disputes concerning the "interpretation and application" of the Convention.

I have determined, pursuant to the authority vested in me as President by the Constitution and the laws of the United States of America, that the United States will discharge its international obligations under the decision of the International Court of Justice in the Case Concerning Avena and Other Mexican Nationals (Mexico v. United States of America) (Avena), 2004 ICJ 128 (Mar. 31), by having State courts give effect to the decision in accordance with general principles of comity in cases filed by the 51 Mexican nationals addressed in that decision". ${ }^{160}$

Thus, although the U.S. government argued against the direct incorporation into domestic law of international obligations emanating from the Vienna Convention, or from the judgments of the International Court, the government proceeded to demand compliance by the states with the Avena judgment on the basis of the President's "constitutional foreign affairs authority and his authority under Article 94 of the U.N. Charter." ${ }^{\text {"161 }}$ In November 2006, the Texas Court of Criminal Appeals rejected the U.S. government's approach, stating that

${ }^{159} I d$., at 33-38.

${ }^{160}$ See Brief for the United States as Amicus Curiae, supra note 150, at attachment (memorandum from President George W. Bush for the Attorney General dated February 28, 2005).

${ }^{161}$ See id., at 42. The United States cited to various cases in support of the President's foreign affairs 
we hold that the President's memorandum ordering us to give effect to the ICJ Avena decision cannot be sustained under the express or implied constitutional powers of the President relied on by Medellin and the United States or under any power granted to the President by an act of Congress cited by Medellin and the United States. As such, the President has violated the separation of powers doctrine by intruding into the domain of the judiciary, and therefore, Medellin cannot show that the President's memorandum preempts [Texas procedural law]. ${ }^{159}$

The final act of the Medellin case is yet to be written, ${ }^{160}$ but for now that U.S. government's approach can be seen with the context of the third antimony. The government's approach maintained the overall democratic and constitutional autonomy of the United States, while simultaneously seeking to achieve compliance as a matter of comity with the International Court's judgment. At the same time, the United States moved to ensure that it would never again be placed in such a position. On March 7, 2005, the government informed the U.N. SecretaryGeneral that it terminated its adherence to the Optional Protocol, thereby foreclosing future cases against the United States before the International Court based on the basis of that protocol. ${ }^{162}$

When one steps back from the intricacies of these cases, the overall thrust of both the Supreme Court's and International Court's decisions may reflect an unfortunate movement away from the normal approaches for mediating the autonomous national law/embedded national law antinomy. In the context of both Breard and LaGrand, the U.S. Supreme Court showed little sensitivity in trying to find a way forward for the United States in a manner consistent with its international obligations. The long-standing approach of the Supreme Court under the Charming

power: United States v. Curtiss-Wright Exp. Corp., 299 U.S. 304 (1936); Amer. Ins. Assoc. v. Garamendi, 539 U.S. 396 (2003); Dames \& Moore, v. Regan, 453 U.S. 654 (1981); United States v. Pink, 315 U.S. 203 (1942); United States v. Belmont, 301 U.S. 324 (1937).

${ }^{159}$ Ex Parte José Ernesto Medellín, 2006 WL 3302639, at*21 (Tex. Crim. App. Nov. 15, 2006).

${ }^{160}$ A petition for certiorari was granted by the Supreme Court in April 2007. See 127 S. Ct. 2129 (2007).

${ }^{162}$ Journal of the United Nations: Programme of Meetings and Agenda, No. 2005/48, at 13 (Mar. 12, 2005) (reporting receipt of the withdrawal on Mar. 7); see Charles Lane, U.S. Quits Pact Used in Capital Cases, Wash. Post, Mar. 10, 2005, at A1. 
Betsy doctrine ${ }^{163}$ to interpret U.S. law, whenever possible and however possible, to avoid clashes with international law seems quite absent through the course of these proceedings. The issue of the death penalty is politically charged in the United States and the issue of federalism is complicated, but the Supreme Court has found ways to uphold international commitments, even in recent years and even in situations where federalism concerns are squarely at stake. ${ }^{164}$

As for the International Court, normally international dispute fora have accepted that they have the power to determine that a state has acted unlawfully and, as a consequence, to order reparations. Such fora, however, have generally avoided ordering of specific performance by a state, preferring not to interfere in internal national processes. While ordering that specific acts be taken internally is by no means unprecedented, ${ }^{165}$ international fora, by and large, accept that the autonomy of states must be respected; that there is only so far an international court or tribunal may go before its authority will be rejected. In the Breard/LaGrand/Avena line of cases, the International Court showed considerable sensitivity to considerations of autonomy when it ordered that the United States, "by means of its own choosing . . . allow the review and reconsideration" of convictions and sentences. Yet despite this, the Court was remarkably willing to assume an authority to oversee the detailed circumstances of criminal law cases unfolding before U.S. state and federal courts, concerning crimes committed in the United States against U.S. nationals, and to order the United States to undertake further review of the cases through its judicial system. Were the Court's judgments firmly anchored in language of the Vienna Convention setting forth what type of remedy should flow from a violation, then the resistance of the United States to the Court's judgments would be much less defensible. As it is, however, it is understandable that the United States was a bit surprised to find that, by joining the Vienna Convention's optional protocol, it inadvertently laid the basis for the International Court to upend U.S. state court proceedings.

${ }^{163}$ See supra note 17.

${ }^{164}$ See, e.g., Garamendi, supra note 161.

165 See, e.g., Arrest Warrant of 11 April 2000 (D.R.C. v. Belg.), 2002 ICJ 33 (ordering Belgium to cancel an arrest warrant issued by a Belgian judicial official because the warrant violated the international immunity of the Congo Minister of Foreign Affairs). On the other hand, it may be noted that, in the Arrest Warrant case, the issuing of the arrest warrant itself was the unlawful act, whereas in Breard/LaGrand/Avena cases the conviction and death 
For Europeans, the concept of a supra-national court reaching decisions that directly affect the lives of individuals is nothing new; the European Court on Human Rights has existed for almost fifty years, and has handed down hundreds of cases that reach deeply into the national legal systems of EU member states. Likewise, the European Court of Justice reaches directly into national legal systems in various ways. Regional human rights courts in the Americas and now in Africa have a less strong pedigree, but nevertheless, for states adhering to their jurisdiction, the concept of such supra-national adjudication as having effects on internal decision-making is understood. For Americans, however, there is no such tradition of allowing intrusion into the U.S. legal system (for example, the United States has never accepted the jurisdiction of the InterAmerican Court of Human Rights).

One often sees reference to the U.S. willingness to adhere to compulsory dispute settlement before the World Trade Organization, and explanations for doing so tend to focus on trade law being a more "technical" area or that the United States is in a relatively weaker position vis-à-vis other states (China, the EU, Japan) on trade matters than on other matters. Those issues are important, but it should also be noted that the outcome of WTO decisionmaking does not directly intrude into the U.S. legal system. There is no mechanism by which a WTO panel decision has a legally binding effect upon an internal U.S. entity, such as a state court. Rather, the result of a U.S. loss at the WTO is that the U.S. government has a choice to make: conform its law or practice; or face WTO-authorized retaliation. ${ }^{166}$

The result in the Breard/LaGrand/Avena line of cases is different. There is no mechanism by which the United States can simply accept that Mexico will also not conduct full-fledged judicial review of the effects of violations of the Vienna Convention (were such an option available, the United States would likely accept it). Instead, the only avenue for redress is that directed by the International Court, which purports to have a dispositive effect on the decisionmaking of sub-state entities. In this sense, adherence to the jurisdiction of the International Court —in terms of its effects on U.S. democratic decision-making and constitutional autonomy- is

sentence were not themselves the unlawful acts.

166 Similarly, in the context of NAFTA Chapter 11 dispute resolution, the United States has a choice: conform its law or practice (invariably, the law or practice of one of the several states with respect to a foreign investor) or pay damages. 
56

considerably different from adherence to WTO decision-making.

\section{Conclusion}

The formal means for mediating antimonies have been largely unchanged since the inception of the Court: the Court has jurisdiction over many disputes, but that jurisdiction is circumscribed (as recognized in Yugoslavia's Legality of Use of Force cases); the judges reflect the global community, but also the major powers; etc. Yet, the Court may have entered a phase where it is more likely to resist the constraints on its power contained within those formal means and less likely to attempt to reconcile antinomies. Although only states may appear before the Court, the Court now finds that a non-state entity (Palestine) may do so if a dispute is submitted in the guise of an advisory opinion. While its jurisdiction is circumscribed, the Court is comfortable engaging in an extended review of the legality of the use of military force by the United States based on a treaty that the Court has found was not violated. While the Vienna Convention on Consular Relations, and other relevant treaties, contain no provisions regarding the effect of violations of the Convention upon national court proceedings, the Court sees no difficulty in determining that U.S. courts must engage in further judicial review of criminal convictions and sentences, trumping local procedural rules. One gets the impression that the Court - fifty years after its creation - is tired of some of the formal constraints that applied earlier in its life and -looking around at the robustness of dispute resolution in other international fora - is ready to expand the reach of its power.

Moreover, it may be that some of the informal means for mediating antimonies have been lost in the past twenty years. While the Court's concern with its reputation and legitimacy in the first thirty years of its existence served as important political constraint in the Court's relationship with all states, including the United States, over the past twenty years that same concern has lead to several clashes with the United States foremost, but also the UK and France. Having stood up to the United States in the Nicaragua case, the Court became a hero to the states of the developing world, and ushered in a period of increased activity on its docket. Of the cases filed before the International Court since its inception, approximately forty percent were filed in 
the last fifteen years. ${ }^{167}$ Thus, while from 1947 to 1989 , the Court received on its docket approximately two cases per year, after 1990 the Court received more than three cases per year. The U.S. withdrawal from the Court's compulsory jurisdiction has far from crippled the Court; arguably, it has enhanced the Court's stature as a place of authority in interstate relations unbeholden to the major powers. For the Court, the lesson may be not to tread lightly with respect to the United States but, rather, to tread heavily unless doing so would be viewed generally as bias.

In its foreign policies, contemporary America appears to be going a different route than much of the world, even its former close allies in Europe. The consequence is that the judges of the ICJ now reflect predominantly the views of states with whom the United States often disagrees. Perhaps this reflects success in the prescription for the Court made by Richard Falk in his 1986 book, Reviving the World Court. ${ }^{168}$ Falk argued for the Court to turn away from what he viewed as Anglo-American and West European ways of thinking, and move more toward reflecting the viewpoints associated with non-Western legal traditions (including, at that time, Marxist outlooks on law). Arguably, this is now what has happened, which has strengthened the Court's position among most states of the world, but seriously alienated the United States.

The antinomies identified in Part II are unlikely to be resolved through the further development of formal or informal techniques for mediation. While the United States is not happy with the decisions being rendered by the Court, there is no support in the global community for altering the formal mechanisms by which the Court operates. If the United States saw concrete benefits in being more closely associated with the Court, it might look for ways to improve relationships, but for the world's premier superpower the benefits appear slim while the costs appear quite high. Consequently, the United States may take steps to further remove itself from the reach of the ICJ's jurisdiction, through terminating some or all of the outstanding treaties that provide for the Court's jurisdiction. In the near term, U.S. policymakers will seek to avoid any involvement in matters before the ICJ, while the Court may well welcome opportunities to speak to the legality of U.S. actions.

\footnotetext{
${ }^{167}$ See Douglass Cassel, Is there a New World Court?, 1 Nw. U. J. Int'l Hum. Rts. 1 ๆ 18 (2004).

${ }^{168}$ Richard Falk, Reviving the World Court (1986).
} 